\title{
Chapter 9 \\ Quality and Equality in American Education: Systemic Problems, Systemic Solutions
}

\author{
Jennifer A. O'Day and Marshall S. Smith
}

\begin{abstract}
After briefly reviewing the unequal opportunities outside schools that contribute to the disparities in educational achievement, attainment, and various indicators of adult success, this chapter zeroes in on addressing inequities within K-12 education. We argue that disparities within the educational system are the product of institutional structures and cultures that both disenfranchise certain groups of students and depress quality overall. Systemic causes require systemic solutions, and we envision a three-pronged systemic remedy: a continuous improvement approach for addressing the quality of educational opportunities for underserved students as well as of the system as a whole; targeted high-leverage interventions consistent with the overall approach but focused on key transition points and needs; and stronger connections between schools and other institutions and systems affecting the development and well-being of children and youth. We then outline a change strategy that incorporates both pressure and support for improvement from three distinct but interacting sources: government and administrative policy (federal, state, and local); professional accountability and networking; and collective engagement of parental, community, and advocacy organizations. We end the chapter with a consideration of recent developments in California and the degree to which they lay the groundwork for moving an equity agenda in the state.
\end{abstract}

Keywords Opportunity • Achievement gap • Accountability • Human capital • Standards-based reform - Continuous improvement approach • Interventions • High-poverty schools $\bullet$ Preschool $\bullet$ Parental education $\bullet$ Segregation $\bullet$ Title I $\bullet$ No Child Left Behind $\bullet$ Common Core

\footnotetext{
We thank David K. Cohen, Richard J. Murnane, Henry Braun, Bill Honig, and Susan Fuhrman for their instructive and insightful comments on an earlier draft of the chapter. We also thank the Spencer Foundation, the American Institutes for Research, the Carnegie Foundation for the Advancement of Teaching, and Educational Testing Service for the resources, time, and intellectual support to complete this work. All errors of fact and inference are the responsibility of the authors.
}

J.A. O'Day $(\varangle)$

American Institutes for Research, San Mateo, CA, USA

M.S. Smith

Carnegie Foundation for the Advancement of Teaching, Stanford, CA, USA 


\section{An Unequal Present}

Education is the great equalizer-or so goes the promise. Yet the chapters in this book and decades of data belie that promise. It is not that educational achievement and attainment are unimportant to mobility and future success- the data confirm that they are. It is that-despite reform attempt after reform attempt-educational achievement and attainment continue to reflect student background: parent education, access to preschool, childhood nutrition and health, individual and neighborhood poverty and segregation. This chapter is about that persistent pattern and what it might take to substantially change it.

\section{Let's Start with the Children}

Born with virtually limitless potential and genetically predisposed to language, learning, and social enterprise, our children represent at once the promise of our society's future and the vestiges of its past and present failures. Much of this book is about those failures - or more specifically about a certain kind of societal breakdown: the systematic denial of opportunity across generations of Americans based on their class, race, geographic location, gender, or national origin. For the children of these Americans, the chance to grow into their full potential is sharply constrained and sometimes squelched altogether by social structures, endemic beliefs, and policies beyond their control or that of their families.

Who are these children? Primarily they are our young people growing up in poverty. Over 16 million children in the U.S. are officially classified as living in poverty; this is $20 \%$ of all children and $25 \%$ of those under the age of 5. Moreover, $40 \%$ of poor children live in "extreme poverty" - that is, in families with annual incomes less than half of the poverty level for a family of four $(\$ 11,746)$. These figures are significantly confounded by race, as children of color are more than twice as likely to be poorer than White children, and a full one-third of all children of color live and grow up in poor households (Children's Defense Fund 2014). ${ }^{1}$

The external conditions in which these young people live and learn have important implications for their preparedness for and participation in school. ${ }^{2}$ Consider the most basic needs: food and shelter. In this the most prosperous nation in the

\footnotetext{
${ }^{1}$ Recent data from the National Center for Educational Statistics (NCES) find that $51 \%$ of U.S. schoolchildren are eligible for the free and reduced price meal program, which some observers have as a majority of U.S. students being in poverty (http://www.washingtonpost.com/local/education/majority-of-us-public-school-students-are-in-poverty/2015/01/15/df7171d0-9ce9-11e4-a7ee526210d665b4_story.html). A more accurate label of "low income" for the figure in this article is used by the original report from the Southern Education Foundation http://www.southerneducation.org/Our-Strategies/Research-and-Publications/New-Majority-Diverse-Majority-Report-Series/ANew-Majority-2015-Update-Low-Income-Students-Now).

${ }^{2}$ See Duncan and Murnane's (2014) excellent treatment of these topics.
} 
world, one in nine children lacks adequate access to food and basic nutrition, which negatively impacts development and school performance (Jyoti et al. 2005). Black and Latino children are twice as likely to be food insecure as their White counterparts. Inadequate nutrition is both a result of insufficient family income and the deterioration of the neighborhoods in which these children live. There are whole census tracts in some U.S. urban centers that are veritable "food deserts," areas that lack grocery stores where residents can buy fresh meat and produce, forcing them to rely instead on prepackaged nutrition-depleted processed foods. ${ }^{3}$ Poor nutrition plus inadequate health care combine to contribute to higher rates of serious medical conditions like asthma, diabetes, and obesity as well as developmental, behavioral, or social delays. And children in poor families are twice as likely not to receive preventive dental and medical care than their more advantaged counterparts and significantly less likely to have health insurance (Children's Defense Fund 2014).

With respect to opportunities for learning and social development, children from poor families are similarly disenfranchised, as low-income parents have few resources to devote to enrichment activities. Indeed, Duncan and Murnane (2014) report that in 2005-2006, the gap between what lower-income and higher-income families spent on enrichment activities was $\$ 8000$ annually, a figure that had tripled since 1972 as inflation-adjusted income disparities grew. Moreover, many children in low-income families live in situations where their parent(s) have little support in parenting and must rely on the TV to babysit. ${ }^{4}$ When of an age for preschool, the majority of low-income students do not attend because there are none available or because their families cannot bear the cost. ${ }^{5}$ A large body of evidence indicates that too many of these children enter school with a working vocabulary and number skills of far less than more advantaged children and without socialization experiences that prepare them for making the most of kindergarten (Yoshikawa et al. 2013). Moreover, children who do not attend a preschool such as Head Start are less likely to graduate from high school and go to college and more likely to get pregnant in teenage years or be imprisoned (Deming 2009).

As they get older, many of these young people have little access to community affordances that middle-income children take for granted-parks, playing fields, sports teams, safe havens. Segregation is a major culprit here. Though residential segregation by race has declined slightly in recent decades, segregation by income

\footnotetext{
${ }^{3}$ The language in the 2008 Farm Bill defined a food desert as an "area in the United States with limited access to affordable and nutritious food, particularly such an area composed of predominantly lower income neighborhoods and communities" (Title VI, Sec. 7527). See U.S. Department of Agriculture (2009). The entire area of West Oakland in California's prosperous San Francisco Bay Area is a case in point. See McClintock (2008).

${ }^{4}$ This problem is exacerbated for children of single parents, who are four times more likely to be poor than children of married couple families (Children's Defense Fund 2014).

${ }^{5}$ The Children's Defense Fund (2014) reports that the average cost of center-based care for infants is greater than the annual in-state tuition for public colleges in 35 states and Washington, D.C. For 4-year-olds the average cost is more than college tuition in 25 states and D.C. Only $16 \%$ of 3- to 4-year-olds attend state-run preschools, and fewer than $40 \%$ nationally were enrolled in any kind of preschool during the period from 2009 to 2011.
} 
has increased: in 2010, $28 \%$ of lower-income households were located in majority low-income neighborhoods, up from $23 \%$ in 1982 (Reardon and Bischoff 2011; Fry and Taylor 2012). And high poverty generally means low services; many of these neighborhoods lack everything from banks to grocery schools to good schools. What they don't lack are sources of stress and trauma. Too many poor children live in neighborhoods that are not safe of drugs, crime, and sometimes physical as well as emotional harm. Often they live in such conditions throughout school and beyond - it becomes one of the few constant features of their young life. And these conditions make academic learning, both inside and outside school, difficult.

While some children in these circumstances-whether through family and community supports, their own personal resilience, or intervention of a successful program or school-are able to overcome the predicted pattern of intergenerational poverty, many others are not. The widening income gaps and erosion of the middle class exacerbate and extend the problem, and the lack of a coherent support infrastructure means that few children and their families have access to avenues out of poverty. ${ }^{6}$

\footnotetext{
${ }^{6}$ Segregation and public and private divestment in high-poverty neighborhoods, particularly those of color, is not the product of residential choice but rather of decades of discriminatory practices and policies (Massey and Denton 1993; Rothstein 2013). Moreover, current approaches to providing safety nets and advancement for the residents of these neighborhoods are woefully lacking. In the U.S., unlike many other nations, the responsibility for health, social services, and income support is spread between the federal government, states, and communities. Though the federal government finances a large portion of these services the funds are distributed according to different rules of multiple programs that have sprung up over the years. Many state governments and communities also provide lists of services for the poor, sometimes in the same sectors as the federal government. While the various levels of government may attempt to act rationally, the forces of politics and ideologies work to create a mix of services that differ in quality and scope from state to state and community to community and often fail miserably to meet the needs of the community. In addition, in many communities and settings, churches and other nongovernmental organizations provide services, some funded by governments and other by philanthropy. All of this creates a bewildering and incoherent patchwork of organizations that, in many settings where there are concentrations of the poor, are often opaque and inadequate to meet daily needs, much less provide the sense of security necessary for the recipients of the services to figure out how to improve their own lives.

The product of distributed federalism in the U.S. that is exemplified by the often-incoherent provision and delivery of support for children from low-income families is unlike the governments of the countries such as Finland, Singapore, and South Korea. The Finnish central government, for example, supports well-organized and coherent systems for delivering health, family support, preschool, and other benefits for all of its population. The importance of predictable and high quality social services for children growing up in poor families is detailed in other chapters of this report. The effects of the incoherence on the probability for success in schools are large and pervasive.
} 


\section{Where Do the Schools Fit In?}

Residential segregation, poverty, low levels of parental education, and limited access to social supports and preschool learning all influence students' educational achievement and attainment, which in turn are strong predictors of adult earnings and civic participation. In this equation, education is a key intervening variable.

We led this chapter with a litany of the environment's challenges for children from low-income families and the importance of social services and enrichment opportunities to support their readiness for school at age 5 and their learning in school as children, youth, adolescents, and young adults. The average number of hours per year that a student is in public school is roughly 1000. The average number of waking hours for the same student during a year is roughly 5500. During the $4500 \mathrm{~h}$ a middle-income student is awake and out of school, the student has a myriad of opportunities for learning experiences that children in low-income families are not offered.

Yet inequalities outside schools do not let schools off the hook. Schools are our society's central institution serving students from all backgrounds and-in theorysupplying them with the knowledge and skills they need to have a fair shot at success in adulthood. That schools can make a difference in children's life trajectories is evident from the isolated but powerful examples of highly effective high-poverty schools that produce success for students who would otherwise be unlikely to progress at pace, graduate, or attend college (see, for example, Cunningham 2006; Kannapel and Clements 2005; Reeves 2003; and Carter 1999). There are even examples of whole districts that have significantly and substantially narrowed gaps in achievement and attainment among groups of students over time. ${ }^{7}$ We discuss several of these in greater detail later on.

Unfortunately, such places are the exception rather than the rule. Indeed, as the Equity and Excellence Commission (2013) notes, "The current American system exacerbates the problem [of unequal opportunities outside school] by giving these children less of everything that makes a difference in education." (U.S. Department of Education 2013, 14). What is this "everything" of which the Equity Commission writes?

\section{Unequal Resources}

One way to approach this question is to consider the most basic learning situation for students in school: the instructional unit. Cohen et al. (2003) define the instructional unit as teachers and students interacting in the presence of content. In this conceptualization, all three of these elements-students, teachers, and contentcould be considered resources that provide opportunities for student learning.

\footnotetext{
${ }^{7}$ These examples include such districts as Long Beach and Garden Grove in California; Union City, NJ; and Montgomery County, MD.
} 
Let's start with students, as the makeup of a school's student body influences access both to high-quality teachers and to challenging content. Poor children are increasingly concentrated in schools and classrooms with other poor children, reflecting both residential segregation and student placement policies within schools. In 2011-2012, $19 \%$ of public school students ${ }^{8}$ attended high-poverty schools (greater than $75 \%$ poverty) and $44 \%$ attended schools with at least $50 \%$ poverty; these figures were up from 12 to $28 \%$, respectively, in 1999-2000. ${ }^{9}$ With respect to race, Black and Latino students attend schools with nearly twice as many students who are poor as White students do. Pervasive in cities, school segregation is also pronounced even in predominantly White suburbs, where $40 \%$ of Black and Latino students attend intensely segregated schools that are at least $90 \%$ Black and Latino (Orfield 2009, 2013).

Studies carried out over several decades find a consistent independent effect of school-level poverty (in addition to the effect of individual poverty) and racial composition on student achievement (see, for example, Perry and McConney 2010; Rumberger and Palardy 2005; and Caldas and Bankston 1997). Concentration of poor students and students of color in certain schools affects the learning environment in multiple ways. Students in these schools are more likely to be in classrooms with schoolmates who have behavior problems and low skills. Student mobility rates in such schools are also higher, which increases disruption in learning for both mobile and nonmobile students (Raudenbush et al. 2011). But most importantly, the concentration of poor students is correlated with the levels of other resources - teachers and other adults, curriculum and instructional materials, facilities, and so on.

In this array of school-based resources, teachers are the most critically important for supporting learning, and study after study indicates that children of color and children in poverty are less likely to be taught by qualified, experienced, and effective teachers (Clotfelter et al. 2010; Isenberg et al. 2013). Summarizing research across varying measures of quality, Adamson and Darling-Hammond (2011) report that students of color in low-income schools are three to 10 times more likely to have unqualified teachers than students in predominantly White schools. Neighborhood environment and low salaries are among the obstacles to recruiting qualified staff in these schools, but poor working conditions-including inadequate support from school administration, disruptions, and limited faculty input in decision making - contribute to a $20 \%$ average annual departure rate among teachers in high-poverty schools (Simon and Johnson 2013; Ingersoll 2004). The constant faculty churn makes it difficult for teachers in these schools to develop a strong sense of professional community, adds to the instability that children in these

\footnotetext{
${ }^{8}$ Educational statistics use eligibility for free and reduced price lunch as a proxy for poverty. Students are eligible for free lunch if their family income is below $130 \%$ of the poverty level; eligibility for reduced-price lunch extends from 130 to $185 \%$ of the poverty level.

${ }^{9}$ For the most NCES recent data, see Snyder (2014, Tables 102.50, 216.30, and 216.60), retrieved from http://nces.ed.gov/programs/coe/indicator_clb.asp on April 12, 2015. Also see Owens et al. (2014).
} 
schools face in other parts of their lives, and exacerbates staff recruitment challenges. Moreover, departing teachers are disproportionately replaced with novices, who on average are less effective than their more experienced peers (see Henry et al. 2012; Kane et al. 2006; Papay and Kraft Forthcoming). Once these teachers obtain a little experience and skill, they also often depart (to be replaced with a new round of novices), creating a pattern of reshuffling of teachers from poor to not-poor schools, high-minority to low-minority schools, and urban to suburban schools (Ingersoll et al. 2014).

Next to teachers in importance is the content to which students are exposed, but again poor students and students of color get less than their more advantaged peers (Schmidt and McKnight 2012). For example, high schools serving Black and Latino students are less likely to offer advanced mathematics, Advanced Placement (AP), and gifted and talented courses than schools serving mostly White students. And in schools that do offer such courses and programs, students of color are less likely to be enrolled in them (Theokas and Saaris 2013).

Underlying many of these differences are disparities in fiscal resources available to schools. Variations in both state and local wealth and commitment to education mean that children in districts in one state may have substantially greater resources than those in another state, and children in one community may have the benefits of substantially different resources than those in another district in the same state. At the state level, the highest spending state (New York) spends three times more per pupil than does the lowest spending state (Utah) (Dixon 2014). Not surprisingly, there is considerable overlap between lower spending states and those with the highest levels of poverty among school-age children. Within states, the same pattern is evident, though there is considerable variation across states in the spending disparities among local districts within their borders. For example, in 2009 states in the Northeast had the highest funding inequities across districts (averaging about $\$ 2000$ per student, or $14 \%$ of the total) while states in the West were among the most equitable with an average disparity of approximately $\$ 1100$ (New America Foundation 2012).

The bottom line is that while poor students need more resources to even hope to reach the level of opportunity of more advantaged students, they actually receive less.

\section{Organizational Dysfunction and Unequal Practices}

Differences in resource amounts are only part of the story. Often neglected by their districts, high-poverty schools are more likely than those of more advantaged students to be dysfunctional organizations with low levels of trust among the adults, ineffective leadership, and incoherent educational programs. Buildings are often poorly maintained and environments are unfriendly (and sometimes unsafe) for staff and students alike. Morale and commitment are often low, making it difficult to motivate and sustain improvements, especially in the face of high faculty turnover. 
Even more damaging are the attitudes toward the students. Low expectations in these schools (and of these schools by their district leadership) have been well documented (see, for example, Boser et al. 2014). Placement policies systematically track poor students and students of color away from higher-level courses, even when they have demonstrated the requisite skills. Discriminatory application of discipline and special education policies results in disproportionate numbers of Black and Latino students (particularly males) being removed from their classes through suspension, expulsion, and placement into restricted environments for "emotionally disturbed" children. ${ }^{10}$ Often these practices are implemented with the best of intentions and with a belief that the policies are fair to all students. The resulting pattern is nonetheless discriminatory, whatever the intentions.

The disparities in opportunities outside school are thus compounded by disparities within our educational systems. It is therefore hardly surprising that the National Assessment of Educational Progress (NAEP) records achievement gaps in mathematics of two or more years between Black or Latino eighth-grade students and Whites as well as between students from low and high-income families. The gaps for reading are slightly smaller. Nor given these patterns is it surprising to find that White students graduate at a rate 13 and 17 points higher than Black and Latino students, respectively (Stetser and Stillwell 2014).

Though these patterns are pervasive and persistent, they are not immutable. Over the past six decades, we have learned a great deal about the learning process, the contributors to unequal outcomes for students, and what it takes to change complex systems. We have also achieved a beginning level of success.

\section{Signs of Progress}

One sign of progress is the positive trend for American students on several aggregate measures of achievement compared both to their counterparts in other developed nations and to the historical data on outcomes here in the U.S. ${ }^{11}$ For example, in 2011, the average scale score in mathematics for all U.S. eighth graders on the Third International Mathematics and Science Study (TIMSS) was 509, nine points above the international average of 500 and 16 points above the U.S. score of 493 in 1995. This represented the sixth largest gain among the 31 countries that took the assessment in both years. (We focus on eighth grade throughout these analyses because they provide a better estimate of overall schooling than those in the earlier grades and represent the whole population of a cohort better than 12th-grade scores,

\footnotetext{
${ }^{10}$ These practices have been well documented in the October 1, 2014, "Dear Colleague" letter from Catherine E. Lhamon, Assistant Secretary for Civil Rights, U.S. Department of Education (Lhamon 2014).

${ }^{11}$ The numbers in this section are based on analyses of NCES data using the NCES Data Explorer (nces.ed.gov/nationsreportcard/NAEPdata/) and International Data Explorer (nces.ed.gov/surveys/ international/ide/).
} 
which do not include dropouts.) In science, U.S. eighth-graders scored ninth at 525, a 12-point gain from 1995 even though science had not been a specific focal point of the U.S. education reform efforts. It is important to note that all of the nations that scored better than the U.S. had substantially lower rates of poverty. ${ }^{12}$ Finland, for instance - with which the U.S. is often (negatively) compared-has a poverty rate of only $5 \%$. By way of comparison, Massachusetts, whose TIMSS scores are the highest of the U.S. state participants in the assessment, has a poverty rate somewhere around 13-15\% and scores that are substantially greater than those of Finland. Indeed, Massachusetts' science results would place it second in the world if it were a country. ${ }^{13}$

Achievement and attainment trends on U.S. measures reflect an even clearer pattern of growth. Eighth-grade mathematics scores on the Main NAEP increased 15 points between 1996 and 2013, a gain of roughly 1.3 grade levels. In NAEP reading, average eighth-grade scores went from 257 in 1994 to 266 in 2013, an increase of nine points, or a little less than one grade level.

With respect to achievement gaps between groups of students, the picture is more mixed. The good news is that there was some narrowing of the gaps between Whites and Blacks and between Whites and Hispanics in mathematics, with a smaller narrowing in reading. In general the growth was consistent over the past two decades for all of the groups, with Whites gaining less than Blacks and Hispanics.

By contrast, there was virtually no overall reduction in the gaps between poor (defined as eligible for free and reduced price lunch) and nonpoor students. In eighth-grade mathematics, for example, both groups increased their performance by 18 points between 1996 and 2013, and the gap remained 27 points or about 2.5 grade levels. Duncan and Murnane (2014) and Reardon (2011) find the same pattern of a reduction in the gaps between White students and Black and Hispanic students while income gaps stay the same or increase.

A second sign of progress is the recent increase in high school graduation rates. The U.S. Department of Education recently released a report showing an overall average freshman graduation rate of $81 \%$ for the nation in 2012-2013. Murnane (2013) in a comprehensive paper points out that the rate was stagnant from 1970 to 2000 and since then shows a substantial overall increase, with especially large

\footnotetext{
${ }^{12}$ Most international organizations measure the poverty rate somewhat differently. They use the metric of $50 \%$ of the disposable median income in the country as the measure of poverty. Using this metric, the Organisation for Economic Co-operation and Development (OECD) number of roughly $22 \%$ of U.S. children in families under the poverty level is very similar to the U.S. number. It places the U.S. 29th of 34 OECD countries-the four countries with higher rates than the U.S. are Chile, Mexico, Bulgaria, and Israel. (See OECD Family Database, CO2.2: Child poverty, http://www.oecd.org/els/soc/CO2_2_ChildPoverty_Jan2014.pdf. See also Max Fisher, "Map: How 35 Countries Compare on Child Poverty (The U.S. Is Ranked 34th)", Washington Post, http:// www.washingtonpost.com/blogs/worldviews/wp/2013/04/15/map-how-35-countries-compareon-child-poverty-the-u-s-is-ranked-34th/).

${ }^{13}$ In eighth-grade TIMSS math in 2011, Massachusetts scored 560, Finland 514, the U.S. average was 510, and the international average was 500. In eighth-grade science, Massachusetts scored 567, behind only Singapore; Finland scored 552, the U.S. 525, and Ontario 521.
} 
increases for Hispanic and African-American students. Using a different metric (adjusted status completion rates for 20-24 years), which he convincingly argues has greater validity than "average freshman graduation rate", Murnane finds an overall $6 \%$ increase in completion rates from 2000 to 2010 to $83.7 \%$. During this time period, Whites gained 4.5 points to $86.3 \%$, while Blacks gained 10.2 points and Hispanic students jumped 13.9 points, both to roughly $78 \% .^{14}$

We suggest two main takeaways from these data. First, the predominant force driving the gaps - and overall achievement levels - is family income and the concomitant conditions associated with it (see previous section). ${ }^{15}$ While race differentials controlled for income have not disappeared, they have declined. This suggests that the independent effect of race/ethnicity is decreasing and that a good portion of the overall racial gap might be explained by the disproportionate percentages of African-American and Latino youth living in poverty. This is not to say that race should be ignored. Quite the contrary. The related effects of discrimination and language and the very high levels of poverty and especially intergeneration poverty among Blacks and Hispanics make it imperative that these issues be treated together.

A second takeaway is that there is both some momentum to build on and much more to be done. The achievement gaps both by race/ethnicity and by income remain unconscionably large, with significant impact on the quality of life and work for far too many of our nation's children. In addition, the positive momentum in achievement appears to apply primarily to tests of more procedural knowledge and of the curriculum of the 1990s and early 2000s NAEP and TIMSS. We do not see the same pattern of improvement, for example, on the Programme for International Student Assessment (PISA), which assesses the ability of students to apply their knowledge and skills in mathematics, science or reading to analyze novel situations and solve complex problems - the very type of performance needed for success in the twenty-first century. On PISA, the U.S. performance has remained fairly stable since the assessment was initiated in 2003, hovering around the international average in science and reading and substantially below the international average in math. This suggests the need to extend and deepen our improvement efforts in education.

The Common Core State Standards for Mathematics and English Language Learning and Next Generation Science Standards (or similar college and career readiness standards) may be a good step in this direction as they are reflective of the types of knowledge and skills that PISA assesses and that students will need in adulthood. To successfully move in this direction, however, requires that we learn from previous reform efforts, a subject to which we now turn.

\footnotetext{
${ }^{14}$ See U.S. Department of Education, "U.S. High School Graduation Rate Hits New Record High", http://www.ed.gov/news/press-releases/us-high-school-graduation-rate-hits-new-record-high; see also Murnane (2013).

${ }^{15}$ It is likely that accumulated family wealth is also a key factor-perhaps even more so than income, but we have no way of validly linking wealth to the NAEP trends.
} 


\section{Observations from 60 Years of Equity Reforms: There Are No Silver Bullets}

Americans have a penchant for quick fixes and easy solutions. We like to do things quickly and if we don't see results right away, we move on to the next new and improved approach. In no arena is this American predilection toward the fast and easy more evident than in education. We have been through numerous reform efforts in the past 60 years, many of them focused specifically on reducing the gaps in opportunities enjoyed by more and less advantaged groups in our society and our schools. We have targeted money at the problem through supplemental funding streams, like the federal Elementary and Secondary Education Act (ESEA) and state categorical programs, and through a myriad of state fiscal equity suits and policies. We have tracked and detracked students, tried homogenous grouping by ability and heterogeneous cooperative learning in the classroom. We have tried pullout and push-in instructional approaches to give extra support to students who need it. We have focused exclusively on academics only to turn around and chide ourselves for ignoring the whole child. We have thought teacher testing and formal qualifications on the front end were the answer to low educator quality, moving more recently to test-driven teacher evaluation as the new required solution. And the list goes on.

While often these solutions have a faddish quality to them-that is, they are popular for a time and then die out when the next new thing or new leader comes along - they are not necessarily without merit or void of at least a promising research base. Indeed, in the past 15 years there has been considerable interest in and policy support for adoption and use of what has come to be referred to as "evidence-based practices." The idea is straightforward: figure out "what works"-usually these are very targeted interventions with a reasonable effect size found in one or more rigorous research studies; adopt and implement the practice at scale; and finally, realize the expected improvements in overall outcomes and gap closings. A corollary to this theme is often the idea that if we adopt multiple evidence-based practices, benefits will cumulate to an overall larger effect. ${ }^{16}$

In the main, we believe that the focus on evidence and effectiveness has been a positive development and has contributed to some portion of the gap closings cited above. But almost invariably, when individual interventions are implemented at scale in schools and districts, the results are far less than anticipated and sometimes disappear altogether. While there are many contributing factors, we see two main interrelated explanations for the diminished effects. First, implementation challenges across multiple and varying contexts lead to uneven and sometimes unforeseen results. Second, individual interventions, usually focused on a specific targeted disparity, often leave untouched the systemic contributors that underlie and

\footnotetext{
${ }^{16}$ For example, see Grannis and Sawhill (2013) for a thoughtful discussion of implications of the Social Genome Project and an estimate of the cumulative benefits of a set of research-based strategies.
} 
perpetuate that disparity. We review each of these problems below and draw out several lessons for moving forward.

\section{Lesson One: Implementation Dominates Impact}

It has been said that implementation is $90 \%$ of impact. The very same intervention applied in one school, locale, or state may yield quite different results than when employed in another. Problems of inadequate resources, weak commitment, or poor fit are often cited to explain disappointing outcomes. This situation is not unique to education; in fact, the field of implementation science, which grew out of concerns about the limited uptake of evidence-based practices in medicine, seeks to apply research on implementation patterns and strategies to improve their application and use across a wide range of social domains. "Implementation varied" is probably the most commonly reported finding across decades of policy and program evaluations. Yet implementation considerations generally get short shrift when policy makers and administrators are considering options and calculating expected impact. Decades of implementation research have yielded a panoply of implementation lessons that could be applied to considerations for equity-oriented policies. Here we focus on three that are integral to our vision of how a more equitable education system would need to operate.

\section{Context Matters}

Research on organizational learning and change holds that all change is history dependent. Schools, districts, and even states differ in their educational histories, including the past performance trajectories, their experience with particular strategies and interventions previously tried, and the expectations that derive from these experiences. They also differ in the makeup of both the adult and the student populations in their systems and the histories that each of these groups has had with schooling, inequality, and change. Varying cultures, conditions, and structures across organizational units and systems can influence the ways in which local actors interpret and act on any given reform or intervention (O'Day 2002, 2008; Spillane et al. 2006). Weatherly and Lipsky's (1977) seminal piece on "street-level bureaucrats," which examined variation across three districts in their implementation of special education in Massachusetts, spawned a host of increasingly sophisticated analyses of the causes and manifestations of contextual variation in implementation.

Attempts to constrain such variation through emphases on fidelity, scripted instructional programs, and one-size-fits-all policies do not solve the problem, as 
they often inhibit professional judgment and responsiveness to individual student and local system needs. Indeed, such approaches may be counterproductive. ${ }^{17}$

\section{Capacity Is a Key Determinant of Implementation Quality and Results}

At the heart of many of the differences in implementation across contexts is their variation in local capacity. Scholars have taken differing approaches to delineating the elements of capacity that matter for improving student outcomes. (Beaver and Weinbaum 2012). All would agree that human capital - the knowledge and skills of individual actors and of the collective body of actors - in a system or site has broad implications for how a given intervention, program, or policy is understood, whether the actors are able to carry out the required or suggested actions, the degree to which the system can adapt to changing conditions and threats to implementation, and so on. Many research-based efforts, from bilingual education to new math or literacy curricula to teacher evaluation rubrics, fail because those who would implement them lack the requisite knowledge and skills. Most observers would also include the amount and appropriateness of available material resources-such as money, instructional materials, and facilities - in notions of organizational or system capacity. Sometimes these resources are the target of particular reform efforts; often they can determine the success or failure of any given strategy. ${ }^{18}$

While people and resources are critical, they are not enough, however. Another aspect of organizational capacity is what several researchers have termed program coherence. Coherence in education implies shared goals and frameworks and the presence of working conditions, structures, and routines that support those goals and allow the actors in the system to focus on their attainment (Newmann et al. 2001; Beaver and Weinbaum 2012). ${ }^{19}$ Like human and material capital, program

\footnotetext{
${ }^{17}$ For example, during the era of Reading First grants, in systems focused on preventing such variation, observers would often encounter references to the "literacy police," administrators whose job it was to ensure that all teachers were following the program on a daily basis as scripted. The intent was to ensure that all students has access to research-based literacy instruction, but teachers argued that the program was often ill-suited to their particular population, including English language learners, special education students, or others who needed specialized attention. Similarly, professional development programs that are designed for all teachers often fail to meet the differentiated needs of most and may not align with the particular issues at a given school or grade level.

${ }^{18}$ One clear example is the implementation of class size reduction in California. While districts received state funds to reduce class sizes in K-3 to 20 or fewer students, many districts, particularly urban systems with already overcrowded and understaffed schools, lacked the classroom space and a pool of qualified teachers to make these reductions effectively. This led to a reliance on portable classrooms and the hiring of large numbers of under-credentialed and novice teachers, who were disproportionately assigned to work in schools serving poor students and students of color. As a result, this massive reform effort, intended to benefit low-income students and schools, actually exacerbated disparities in access to qualified and experienced teachers and adequate facilities (Bohrnstedt and Stecher 2002).

${ }^{19}$ Conversely, program coherence implies an absence of factors that detract from or inhibit implementation.
} 
coherence is not equitably distributed across schools and districts. We have already noted the organizational dysfunction that characterizes many high-poverty schools, caused by years of neglect, environmental stresses, and high rates of staff turnover. A similar observation could be made of many low-capacity districts. One manifestation of this incoherence is either a flitting from one reform effort to another in search of the panacea or the accumulation of multiple interventions and programs-some well-intended and researched but all vying for attention and resources. Lack of coherence in high-poverty schools and districts makes it difficult for teachers and administrators to select and adapt strategies that build on one another and enhance their ability to systematically address the learning needs of their students.

\section{Implementation Is a Social Process}

The past few decades have brought increasing attention to the importance of social capital and trust for diffusing effective practices and for enhancing learning and improvement in the conduct of one's daily work. Social capital resides in the relationships between and among people, groups, and organizations (Coleman 1988). For effective implementation to occur, these relationships must be activated, not just once but through multiple interactions on an ongoing basis. ${ }^{20}$ Unfortunately the isolation of schools and teachers that is common in American education systems generally is exacerbated in high-poverty contexts where turnover and lack of trust impede the development of strong relationships that can mobilize implementation of evidence-based practices. Thus, even those interventions that are specifically designed to benefit such systems and the children and adults in them often never find their way where they are most needed. Attempts to ensure spread and implementation through administrative mandates do little to solve this problem and often lead to superficial compliance without deep understanding or committed action. When the pressure subsides, so does reform.

\section{Lesson Two: Piecemeal Reforms Leave Systemic Contributors Untouched}

Underlying many of these implementation challenges is the fact the isolated and piecemeal reforms often fail to address underlying systemic contributors to the very situation or inequity that they are attempting to address. Take the example of incentive programs that are designed to attract more qualified and effective teachers to work in high-poverty schools but leave untouched the dismal working conditions that cause turnover in the first place (Ingersoll 2004; Simon and Johnson 2013). Or

\footnotetext{
${ }^{20}$ See Rogers et al. (2009) for a discussion of the importance of social relationships in implementation, and Gawande 2013 for how this plays out in healthcare. For a discussion of the role of social learning in the conduct of one's daily, see Bransford et al. (2015) and Bryk et al. (2010).
} 
consider school accountability policies that penalize schools for low performance but let districts off the hook, leaving unaddressed the policies and practices that concentrate low-performing students and inexperienced teachers in those schools and pay insufficient attention to building the capacity for long-term improvement.

In each of the implementation challenges discussed above, the success of individual reforms is constrained or thwarted by conditions endemic to the system itself. What's more, incoherence and instability in the policy environment make it difficult to identify and change these conditions. Superintendents, school boards, and legislators come and go, but disparities in resources and practices go on, bolstered by institutionalized structures and beliefs. Edicts from the federal government and states are often contradictory and ill suited to the specific and varied conditions across contexts. Fragmented governance, politics, top-down compliance, inadequate data systems, bureaucratic human resource policies, and isolation of schools from other systems and organizations affecting children's welfare combine to reinforce existing disparities in resources and processes. On the ground, schools in high-poverty neighborhoods lack the information, trust, and capacity they need to examine their practices and results over time and are pulled in multiple and conflicting directions by the mixed messages they receive. High-stakes testing and accountability measures can compound these issues and have the effect of drawing attention to avoiding consequences for adults rather than ensuring progress for students. ${ }^{21}$

Seeing the limitations in the current system as insurmountable barriers, some politicians and reformers have turned to charter schools and school choice as answers, a way to remove regular public schools-particularly those serving poor students and students of color-from a system that has repeatedly failed these children. Though promising in many ways, however, charters are no more a panacea than any other intervention. They free schools from many constraints and allow more innovation and experimentation, but much of the research suggests that most charter schools are quite similar to public schools in both their organization and results (Raymond et al. 2013). Charters could serve as a learning ground for the larger system and the field as a whole, and some districts have made use of their charters in this way. In most cases, however, mechanisms for feeding information back into the larger system, in ways that it can be effectively used, are either limited or absent altogether. As a result, charters as a whole do little to address the situation for the vast majority of underserved students in American schools. ${ }^{22}$

\footnotetext{
${ }^{21}$ For discussions of the effects of current high stakes testing policies on schools, see Schoen and Fusarelli (2008); Berliner (2011); and Cawelti (2006).

${ }^{22}$ Schools associated with a few of the charter management organizations (CMOs) - deliberately formed groups of charter schools that are similar in vision and strategy - do show signs of significant success. They include Aspire, KIPP, Achievement First, and High Tech High among others. One way of thinking about these CMOs is that they are public systems freed from many of the regulatory constraints of regular public districts and schools. Another way to think about them is that they could be compared to effective districts as they serve many of the same functions and demonstrate similar characteristics.
} 


\section{Vision of a More Equitable Education System}

What are the implications of our discussion of educational inequalities and lessons from equity-based reforms? What might a more equitable education system look like? And how might we more effectively move in that direction, not only for a few schools and districts but across whole systems and states? In the next section, we draw on our previous discussion and on 20 years of systemic standards-based reform to sketch out a vision of how a more equitable education might operate in the U.S. We argue that to address the deep and pervasive inequities we've described requires a system-wide focus on quality improvement within a standards-based framework, combined with targeted interventions to address particular and pervasive disparities within schools, and coordinated efforts between schools and other agencies and organizations serving children and their families. In the final two sections of the chapter we turn to the problem of motivating and supporting change toward such a vision and provide an example of a state working to move in this direction.

Three assumptions frame the focus and limit scope of the vision we present. First, we recognize that the ecosystem in low-resourced and often dysfunctional environments in cities and rural areas affects both the social system outside of the schools and the schools themselves. We thus assume that changes in both the outof-school opportunities and the within-school opportunities are necessary if we wish to dramatically reduce student achievement and attainment gaps. However, we also assume - with considerable evidence to back this up — that schools can make a major difference. Though we believe it is necessary to figure out promising ways to ensure that all children have a real opportunity to be ready for school, that they and their families live in supportive environments, and that they have opportunities for employment beyond their schooling, we leave this task to other authors in other chapters of this volume. We focus here on the schools.

Second, we assume the American educational system will not change in its general form in the next decade or two. We do not propose to "blow up the system," however appealing that might be to some. While we expect that technology will influence to some considerable extent how students learn and teachers teach-especially as older teachers retire and new teachers come in having been raised in the Internet era-we anticipate that for the foreseeable future we will continue to have schools where most students come together to learn, that this learning will take place over 13 grade levels (K-12), and in classes of 15-30 students. We also expect that districts and district school boards will continue to exist and set the rules at the local level and bargain with the local unions. We expect charter schools to remain as an alternative for some small portion of students.

Finally, we recognize that the conditions we outlined in the beginning of this chapter do not simply diminish opportunities for traditionally underserved students. They also depress the quality of schooling for all —or at least the vast majority of students in U.S. schools. International comparisons demonstrate the limitations of American educational opportunity. These data and our earlier discussion suggest 
quality and equality are interactive concepts. Any approach to improving equality of opportunity must pay attention first and foremost to the quality of the schools and school systems and their ability to improve conditions for students over time. At the same time, any attempt to improve the quality and outcomes of our educational systems overall will be successful only to the extent that it also reduces disparities and fosters success for those who have traditionally been least successful in school.

\section{The Foundation: A Quality School System}

Our analysis of the recent era of educational reform in the U.S. as well as of more successful systems both here and abroad leads us to posit two core elements of a high quality system: a standards-based and supportive policy framework and a continuous improvement approach at all levels of the system.

\section{Coherent Standards-Based Policy Framework}

The odds of success for a school with a population that has lacked important opportunities are substantially increased if it operates in a supportive environment where its internal (school) and external (district, state, and federal) leadership are all pulling in the same direction. This is the central tenet of standards-based reform, a systemic improvement strategy first articulated in the late 1980s and subsequently spread through federal and state policy across the nation. In its original conception, standards-based reform encompassed three key components: challenging standards stating what students should know and be able to do for graduation and at different points in their schooling, a coherent system of mutually reinforcing policies designed to build capacity and focus to ensure that all students had access to opportunities to achieve those standards, and a redesigned governance system in which top-down direction was combined with bottom-up discretion, knowledge, and professional energy of school people and their communities (Smith and O'Day 1991). This early conception grew out of efforts of professional associations to professionalize teaching and define standards in the disciplines, research evidence on the limitations of top-down mandates that only intensified current practice, and an analysis of the ways in which a fragmented policy and governance structure hindered the spread of effective school-based innovations and overall improvement efforts. Equity goals have been at the heart of standards-based strategies since their inception, reflecting the belief that all students should have access to high-quality curriculum and instruction and that a coherent set of policies guiding instructional content, professional development, resource allocation, assessment, and accountability could stimulate and support change in that direction (O'Day and Smith 1993, 272).

Over the past two decades, stimulated in part by federal action in ESEA and Goals 2000 legislation, all states have adopted standards and have instituted at least some degree of policy alignment to those standards. Most are currently in the 
process of shifting to a new generation of college and career-ready standards that better reflect the depth of knowledge and skills needed in the fast-paced and complex world of the twenty-first century. Indeed, the notion that states should articulate and use content standards to guide their education systems - unheard of in the U.S. before the 1980s - has now become conventional wisdom. The pervasiveness of some form of standards-based reform at the state level not only makes it difficult to envision a system in the near future without such standards; it also provides a plausible explanation for at least some of the achievement gains and gap closings observed in the NAEP and TIMSS results cited earlier.

Yet standards and aligned policies are not enough. While systemic in nature, standards-based approaches have fallen prey to many of the same implementation challenges we discussed above for more piecemeal efforts. Early emphasis on support for capacity building, for example, never fully materialized or was not sustained in most jurisdictions. And the notion of an altered governance structure that would allow for context-embedded solutions and responsiveness gave way to an almost singular focus on accountability and top-down mandates (many of them federal) during the No Child Left Behind (NCLB) era. The Obama administration's use of the waiver process to allow for greater state flexibility does not adequately address this problem, for while changing some of the parameters of the NCLB requirements, the Department of Education has maintained the strong focus on accountability as a central lever for change. It has even extended the accountability emphasis to single out test-based teacher evaluation as the favored approach for improving teacher quality (see Jennings 2015 for a fuller discussion).

We continue to believe that a state-level systemic approach based on thoughtful and challenging content standards can provide a scaffolding and structure for the academic activities of schools and classrooms. Multiple states provide existence proofs for this assertion. In addition, within this general approach, we see the Common Core and Next Generation Science Standards as significant and positive steps forward, both because of the content of the standards themselves and because of the potential for collaboration and mutual learning across states. ${ }^{23}$ In particular, the increased emphasis on using language orally and in written form and the focus on depth and understanding rather than on algorithms can provide a stronger base for students to successfully enter the environment beyond schooling than is presently offered in most schools.

Yet the promise of the standards to improve overall system quality and reduce disparities for poor students and students of color cannot be realized without focused and persistent attention to implementation and the processes of change and system improvement.

\footnotetext{
${ }^{23}$ Even with the political pushback against the Common Core State Standards per se, we see a trend toward greater depth and commonality in the standards across states. We expect for a large majority of states this trend will hold.
} 


\section{A Continuous Improvement Approach}

The second core element of a high-quality system is the simple but demanding concept of continuous improvement, which is a logical extension of our earlier observations about the importance of contextual conditions and systemic contributors to the success of any effort to improve outcomes for traditionally underserved students. An outgrowth of W. E. Deming's work in Japan, continuous (quality) improvement has been a focus for research and organizational change efforts in both public service and private industry for decades. A recent comprehensive review of this work identified five core features of quality improvement across a variety of approaches:

1. It is focused on system outcomes for a defined population of beneficiaries-and on the processes that lead to those results;

2. It uses variation in performance (including "failure") as opportunities for learning and improvement;

3. It takes a system perspective, with the understanding that systems are designed to get the results they produce, so if you want to change the results, you have to change the system;

4. It is evidence-based, including measurement of not only outcomes but processes (and resources), and this measurement is embedded in the day-to-day work of the system and its participants: and

5. It involves a specific and coherent methodology and processes. Some of the more familiar methods include PDSA (Plan-Do-Study-Act) cycles, "Six Sigma," and "LEAN."24

While specific methodologies differ, continuous improvement processes generally start with identification and analysis of a problem of practice in the given system, followed by repeated cycles of inquiry in which a plan for addressing that problem is developed, tested, revised based on data, and then implemented more broadly (or retested anew), followed by new data and more refinement. Most authors discuss quality improvement as a necessarily ongoing activity, often involving multiple cycles over periods of 7-10 or even more years to address major performance problems. For Tony Bryk and his colleagues at the Carnegie Foundation for the Advancement of Teaching, a critical feature of an improvement approach is not simply the repetition of the cycles of planning, action, and feedback but also the integration of continuous improvement processes into the daily work of individuals throughout the system..$^{25}$ Collaboration and active involvement of system participants allows for more effective individual and organizational learning, diffusion of promising practices, and adaptation to changing conditions (both internal and external) - all aspects of the implementation challenges discussed earlier. Such collaboration has repeatedly been identified as a central feature of more effective schools

\footnotetext{
${ }^{24}$ See Park et al. (2012) for a review and synthesis of the continuous improvement literature. For a more detailed treatment, see Langley et al. (2009).

${ }^{25}$ See Park et al. (2012) and Bryk et al. (2011) for more detail on the conceptual underpinnings of the promising work of the Carnegie Foundation for the Advancement of Teaching.
} 
and districts (see, for example, Purkey and Smith 1983; Sykes et al. 2009). When expanded across systems in what the Carnegie Foundation calls "networked improvement communities," such collaboration allows for collective examination of both common and context-specific patterns of change and adaptation (Bryk et al. 2011).

Continuous improvement approaches have been put to productive use in many sectors and have had a particularly profound impact on improvement of health care organizations, both in the U.S. and internationally. ${ }^{26}$ One longer-term example in education is that of the Long Beach School Unified School District in Southern California, which has been consistently applying these concepts over the period of two decades with a focus on increasing outcomes for traditionally underserved students, who make up over $70 \%$ of the student population. ${ }^{27}$ That work has been documented in three case study reports published by the Harvard Business School since 2006. ${ }^{28}$ Winner of the prestigious Broad Prize in 2003 and a finalist in 2007 and 2009, Long Beach has also recently been named as one of the top three school systems in the country by McKinsey \& Company in terms of sustained and significant improvements. The impact of those improvements can be seen not only in overall gains in student achievement and graduation but in narrowing of gaps over time: gains for the district's African-American, Latino, and poor students on the state's Academic Performance Index between 2002 and 2012 were approximately $50 \%$ higher than those for Whites.

\footnotetext{
${ }^{26} \mathrm{See}$, for example, the work of the Institute for Healthcare Improvement (IHI) at http://www.ihi. org/Pages/default.aspx

${ }^{27}$ One small example of how this process works in Long Beach is the development of the district's K-8 mathematics program over an eight-year period. The approach began in 2003 when a single teacher (Si Swun) applied the principles of Singapore Math to his own fifth-grade classroom, with remarkably positive results. Singapore Math combines the development of students' conceptual understanding of mathematics with the automaticity of basic math facts and procedures. Within a year, other teachers in his school were adjusting their math instruction in similar ways, also to good effect. The district decided to test out the approach in other contexts, first in fifth-grade classrooms in five high-need schools. Based on positive results in these schools, the pilot program (entitled MAP $^{2} \mathrm{D}$ ) was spread to 15 schools, with expansion in several of these to second and third grades. The testing and expansion to new schools and grades continued over the next several years until the district had enough data to warrant full implementation across all elementary schools. In addition to teachers and schools following the progress of their own students, the district research office conducted a quasi-experimental evaluation of the implementation and effects of the program. The first evaluation report, based on 2005-2006 data, found that the students in the MAP ${ }^{2} \mathrm{D}$ classrooms were scoring significantly and substantially higher than comparison students and almost as well as students of higher socioeconomic status in other schools. Subsequent evaluations bolstered these findings. In 2009, Long Beach partnered with Fresno Unified School District to expand the approach beyond the elementary grades into middle school, assessing the results across the two systems and revising the process. For an evaluation of $\mathrm{MAP}^{2} \mathrm{D}$ in Long Beach, see Anderson and Gulek (2008); for details on the partnership in mathematics with Fresno, see Duffy et al. (2011).

${ }^{28}$ See the three case studies of varying aspects of Long Beach's work during this extended periodproduced by the Public Education Leadership Project of Austin Harvard University's graduate schools of education and business: Austin et al. 2004, 2006; Honan et al. 2004.
} 
Next door to Long Beach is Garden Grove. In a variation of the strategy, over a 14-year period, Garden Grove has focused on improving its human capital in all areas of the district to similarly positive results (Knudson 2013). Other documented district examples include Union City, NJ; Montgomery County, MD; and Hillsborough and Orange Counties, FL (see, for example, Kirp 2013). The Sanger School District in California's impoverished central valley demonstrates these principles for a smaller, mostly rural district (David and Talbert 2013).

These are only a few of the U.S. examples. At the state level, Massachusetts and Texas fit the pattern of a sustained effort based on evidence to improve all parts of the system. And internationally, much has been written about the improvement processes of Finland, Singapore, and the province of Ontario in Canada. Two key questions emerge that are particularly relevant for our discussion of equity.

\section{Continuous Improvement (CI) and Outcome Accountability}

The most obvious question is how a continuous improvement approach differs from typical school and district accountability models instantiated in NCLB and other common policies (Hargreaves and Braun 2013). After all, outcome accountability also focuses on the application of data to identify where things are not workingand particularly where they are not working for traditionally underserved students. For example, the reporting of student outcomes disaggregated by historically significant subgroups has been a main contribution of Title I legislation since 1994. However, we see at least four fundamental differences that distinguish an accountability-based approach and a continuous improvement approach.

First, accountability-based models usually focus exclusively on collecting and analyzing data on student outcomes. But without systematic information about the antecedent processes, teachers, schools, and districts will have difficulty connecting those outcomes with their likely causes; nor will they be able to meaningfully assess the impact of actions they take to alter those outcomes. ${ }^{29}$ By contrast, the focus in $\mathrm{CI}$ is on the improvement of practice, and so detailed information about particular practices is part and parcel of the analytic method. Moreover, the analytical methods employed are specifically designed to facilitate meaningful connections between processes and outcomes.

A second difference between the two approaches is the perspective on failure. In CI, mistakes and failures are expected; they are both the basis for identifying the focal problem of practice and are opportunities for collective learning about how to make things better. In addition, frequent, rapid cycle tests of possible solutions also help to minimize harmful mistakes when the knowledge base for any particular problem or remedy is weak. By contrast, failure and mistakes in typical accountability systems are more frequently opportunities for blame and negative consequences than for assistance and learning. As a result, participants often try to hide problems rather than address them openly and may even "cook the books" to avoid

${ }^{29}$ See O'Day (2008) for a more complete discussion of this issue. 
recriminations and penalties. The test cheating scandals in which teachers and administrators change student answers to "improve" their scores are reflective of this problem. ${ }^{30}$

The approach to context is a third difference. Accountability models typically mandate not only the targets and measures but also the solutions to unsatisfactory outcomes, irrespective of their appropriateness for a given context-and often irrespective of the strength of the evidence behind them. In continuous improvement, all solutions are contextualized, and trials across multiple contexts provide information about which solutions are likely to work for whom and under what conditions.

Finally, the two approaches differ with respect to the primary source of accountability. In most education systems today, accountability is something that comes from outside the school or district. Local actors have not been involved in setting their goals or often even in determining their strategies. In continuous improvement, while there may be some externally determined targets, the primary source of accountability is internal among members of the organization and its clients and focused on the practices and feedback loops they have put in place. Case studies of low-performing schools conducted by Consortium for Policy Research in Education researchers found that this internal accountability distinguished those schools that were able to improve their performance over time from those that did not (Abelmann et al. 1999).

\section{Continuous Improvement and Equity}

A second question particularly relevant to the topic of this chapter is whether a continuous improvement approach will actually lead to reductions in opportunity and outcome gaps among students. While we believe that such an approach will foster the conditions under which strategies for reducing disparities can be most successful, we would argue that addressing these inequalities must be an explicit goal of the system for this to happen in a systematic way. The case of Montgomery County, $\mathrm{MD}$, provides an example of how this process works in practice.

When Jerry Weast became superintendent of the Montgomery County district in 1999, he instituted a continuous improvement approach to address the large and nationally comparable gaps between White students and their African-American and Hispanic counterparts. GIS mapping of regions in the county that were high poverty, high minority, and low achieving provided a graphic catalyst for communitywide dialogue about educational disparities and race. Discussions across the district helped to identify structural contributors (like course placement policies in high school that tended to keep Hispanic and African-American students from higherlevel courses because they lacked the prerequisites) as well as adult norms and attitudes that prevented full access for some students. Multiple sources of dataincluding frequent "walk through" observations using formal protocols in individual

\footnotetext{
${ }^{30}$ See, for example, Fair Test's 2011 fact sheet on these issues: Tests, Cheating and Educational Corruption, http://fairtest.org/sites/default/files/Cheating_Fact_Sheet_8-17-11.pdf
} 
school sites-helped district leaders to identify particular manifestations of unequal opportunity and to design interventions such as full-day kindergarten, small classes, and rigorous curriculum models, which they targeted to high-poverty schools. They monitored for success of these actions over time while creating a system-wide culture of collaboration focused on both excellence and equity. By the end of Weast's 12 -year tenure, Montgomery County had significantly reduced gaps among racial groups across multiple performance indicators: achievement on state tests in elementary school, completion of algebra in eighth grade, SAT and Advanced Placement (AP) results, and high school graduation. Indeed, the county posted higher AP participation and success rates for African-American students than the nation did for students as a whole (Weast 2014).

Similar examples of a focus on equity and access within a process of continuous improvement can be found in most of the districts previously mentioned. In Fresno, for instance, a six-year partnership with the University of California has produced sophisticated data systems to uncover disparities in course-taking patterns and other opportunities for underserved students, which the district and its partners have systematically addressed with substantial success through ongoing work with school counselors, principals, and district administrators. Less than 200 miles away, the Oakland Unified School District has been working with local funders and nongovernmental organizations (NGOs) to monitor and address disparities for AfricanAmerican youth in seven areas through the African-American Male Achievement Initiative. Based on data collected and analyzed by the district and the Urban Strategies Council, the initiative focuses attention to students' developing identity, social emotional health, and academic learning to reduce achievement and graduation gaps, increase attendance, and eliminate disparities in disciplinary actions and incarceration. In these and similar cases, continuously improving districts explicitly and systematically interrogate their data to ferret out disparities that might not be immediately apparent, collaborate to tease out potential root causes and devise strategies, and test and evaluate those strategies over time.

\section{Targeted Strategies to Reduce Inequalities: Four High-Leverage Approaches}

As these examples demonstrate, a great strength of embedding continuous improvement into the fabric of a school system is that the system can more readily identify gaps in outcomes and opportunities among students and efficiently target action in those areas. These include ongoing monitoring of access to such resources as qualified teachers and teacher time, advanced courses, and appropriate and high-quality instructional materials as well as elimination of disparities in disciplinary actions and extracurricular opportunities. In this section, we highlight four high-leverage arenas in which such targeted attention and action for students can help to level the playing field and substantially reduce within-system inequalities. They are 
development of a physically and emotional safe school environment; a strong emphasis on cultivating robust language capacities in all students; a methodology (tiered instruction) for systematically thinking about the nature and intensity of interventions; and attention to key transition points that may be particularly difficult for disadvantaged youngsters to traverse and require special interventions.

\section{Ensuring Safe and Supportive School Environments}

Safety is one of the first things that parents think about when their child goes off to school. Schools in high-poverty neighborhoods are much more likely to be unsafe. Minorities and "different" children often face emotional and physical safety problems in all schools. ${ }^{31}$ At a basic level, physical safety and protection from outside influences capture the public discourse, and districts and schools across the country use a variety of approaches to ensure that safety. We address here the issue of physical and emotional safety in terms of conditions and actions inside the school.

The idea of supportive school culture and climate has been an important element in the school reform discourse for years. Such an environment supports not only a positive place to work but also a more effective organization.

Recent research has broadened this concept to focus on a broad span of socialemotional skills and dispositions of students and adults that support productive interaction and respect for everyone in the school. These skills and dispositions are captured in the research on Social-Emotional Learning (SEL) ${ }^{32}$ and undergird the development of a school with a physically and emotionally safe environment. SEL is the label for a growing movement throughout the U.S. for schools and districts to move beyond a narrow focus on academic content and skills. ${ }^{33}$ It emphasizes five interrelated sets of cognitive, affective, and behavioral competencies: selfawareness, self-management (often called self-regulation), social awareness (including the capacity for empathy), ability to establish and maintain healthy and rewarding relationships, and responsible decision-making. The competencies provide a framework for specific and detailed interventions such as the "Second Step" and the "Steps to Respect" programs. ${ }^{34}$

\footnotetext{
${ }^{31}$ See, for example, Lippman et al. 1996; Erica Weiler 2003, "Making School Safe for Sexual Minority Students," Principal Leadership, June, http://www.nasponline.org/resources/principals/ GLBQT\%20Safety\%20NASSP\%20December\%2003.pdf

${ }^{32}$ For a deeper discussion of SEL, see the website of the Collaborative for Social and Emotional Learning (CASEL) at http://www.casel.org/social-and-emotional-learning/outcomes/. See also the website for PromotePrevent, http://sshs.promoteprevent.org/publications/prevention-briefs/ social-and-emotional-learning

${ }^{33}$ States are taking account of SEL. For example, Massachusetts has a set of guidelines for implementing SEL. See http://www.doe.mass.edu/bullying/SELguide.pdf

${ }^{34}$ For a review of the research on social-emotional learning and Second Step, see the Committee for Children website at http://www.cfchildren.org/Portals/0/SS_K5/K-5_DOC/K-5_Review_ Research_SS.pdf
} 
Schools that pursue these goals do so explicitly: Students and parents are regularly engaged, and teachers work to ensure that classroom behavior and opportunities meet the goals of SEL. This kind of focus takes time and energy to implement well but it seems to be worth the effort. A rich literature of studies provides clear and positive evidence on many of the SEL dimensions. For example a recent metaanalysis of SEL's effect on achievement found an average gain of 10 percentile points while other studies have found clear positive effects of SEL interventions on areas such as bullying. ${ }^{35}$ The implementation of SEL in a school can do more than change the ways that students behave in classrooms and the halls. It also creates an environment where students can be different from the norms established by advertisements and video. It can change the way people think about each other.

The components of SEL are exemplified in the use of "restorative justice," or "restorative practices," a set of principles and practices focused on promoting respect, taking responsibility, and strengthening relationships. ${ }^{36}$ The idea of restorative justice has a long history in areas other than schooling and in a variety of cultures. It changes the focus from punishment to repairing harm. In many schools, instances of bullying, fighting, and threatening have led to disproportionate numbers of students of color and males being subjected to punitive discipline-suspensions and expulsions - that remove them from instructional settings. Restorative justice deals directly with this issue. Oakland and San Francisco have made restorative practices key components of their equity and improvement agendas.

\section{Developing Language Skills}

The limits of my language means the limits of my world. -Wittgenstein

Language development is affected by everything that happens to a child-from the mother's prenatal nutrition and habits (smoking, drinking, drugs) to language use in the home, including whether the child is read to or expected to ask and answer questions and engage in extended dialogue. The well-known Hart and Risley study (1995), comparing children in poor, low-income, and middle-income families, found huge differences in the amount and quality of expressed and understood language, favoring the children in the more advantaged families. ${ }^{37}$ The literature on preschool and language development is clear. Young children living in poverty who have not attended preschool are very likely to be behind in their language develop-

\footnotetext{
${ }^{35}$ For a meta-analysis of the multiple effects of social-emotional learning interventions, see Durlak et al. 2011.

${ }^{36}$ For a review of the effects of restorative justice programs, see Latimer and Kleinknecht 2000. For additional description of restorative justice and its relation to SEL, see the report of the Restorative Practices Working Group at http://www.otlcampaign.org/sites/default/files/restorative-practicesguide.pdf

${ }^{37}$ See Hart and Risley (1995). See also http://www.naeyc.org/blogs/gclarke/2013/10/new-researchearly-disparities-focus-vocabulary-and-language-processing
} 
ment when they enter kindergarten. Students in this situation should be carefully monitored as they learn to read, with special attention to broadening their vocabulary and increasing their facility and comfort with the academic language of the schools. If the interventions come early and with sufficient intensity, the odds are good that students will gain the necessary skills and breadth of language that they need to succeed educationally. The new evidence of robust and positive long-term effects of Head Start is particularly promising in this regard. ${ }^{38}$

Once in school, students continue to learn conversational and academic oral English through the first years of schooling as they are also learning how to read and comprehend text. Without a strong language base, reading comprehension in the higher grades is a great challenge. By middle school, the teachers in the content areas assume that a student can understand the language in the classroom, integrate knowledge with past experience, and understand complex literary and nonfiction texts. Secondary teachers often have too little time and too many students to systematically identify and help students who are struggling to keep up. ${ }^{39}$

The need (and opportunity) for strong language development has been intensified by the college and career-ready standards recently adopted by most states. These standards emphasize learning to use oral language to explain answers to problems, make a logical argument based on evidence, interpret text, and retell stories. Academic language is part of word problems in mathematics and in science explanations. History, as told in books, movies, or video, is a matter of understanding a complex story; without strong language skills a student struggles. The assessments for the Common Core mathematics standards contain problems with large "stems"- two or three paragraphs of setting out the problem before the questions are posed. Even in math, the capacity to understand the language of the problem is critical to knowing how to set up and execute its solution (see Bransford et al. 2015; Snow et al. 1998).

For students who come to school speaking a language other than English at home, language development takes a particular form and challenge. On the one hand, the research is pretty clear on the cognitive benefits of bilingualism for all students. ${ }^{40}$ In addition, in an increasingly global economy, students with native fluency in other languages and cultures can be a wonderful national resource. On the other hand, English language learners (ELLs) in schools face the double challenge of learning increasingly sophisticated and demanding content and learning a new language at the same time. Combining instruction in their native language with instruction in English can be an effective way to increase acquisition of English, ensure higher levels of content learning, and enable maintenance and development

\footnotetext{
${ }^{38}$ For a general discussion of the effects of Head Start and other early childhood programs, see Heckman 2011. For long-term effects, see Deming (2009) (http://www.people.fas.harvard. edu/ deming/papers/Deming_HeadStart.pdf) and Gibbs et al. (2011) (http://www.nber.org/papers/ w17452.pdf).

${ }^{39}$ For a delineation of these issues, see Johnson et al. n.d.; Vaughn et al. 2008.

${ }^{40}$ For reviews of the research on the cognitive benefits of bilingualism, see Goldenberg (2008) and Bialystok (2011).
} 
of ELLs' native languages. Bilingual education - particularly dual immersion programs - can also spread the benefits of bilingualism to native English speaking students. ${ }^{41}$ Making it possible for students in low-income areas to be in bilingual classes whenever they enter the U.S., but especially in the early years, would be challenging to accomplish but well worth the effort.

\section{Implementing a Tiered Approach to Intervention}

Response to Intervention (RTI) is a three-tiered methodology that provides a structure for teachers to select and implement an appropriate intervention for a student or students who require special attention..$^{42}$ Without some well-organized and defined strategy, students will slip through cracks. One major goal of RTI is to address problems very early to reduce the odds of students experiencing failure.

The first tier of RTI is a well-organized and effectively implemented curriculum and inclusive instructional approach: All students are involved and expected to be mastering the content, and instruction is specifically designed to address the wide range of learner needs, strengths, and backgrounds ${ }^{43}$ Regular monitoring of student learning is a critical aspect of first-tier instruction, with the goal of addressing problems or barriers to learning before they become serious. Interim assessments can play a role in this monitoring but are often not timely or fine grained enough to enable the teacher to respond effectively to individual student needs. More critical is the teacher's capacity to observe how well students are learning the material on a minute-by-minute and day-by-day basis through the use of formative assessment and observation along the lines described by Black and Wiliam (2009). Black and Wiliam see this process as continuous, with the focus on preventing students from long-term confusion or withdrawing their attention from learning. With a strong core instructional program that is inclusive and incorporates formative assessment practices, $75-80 \%$ of students can be sufficiently served.

The second tier of RTI is for students for whom the core program is insufficient; that is, for those who regularly do not seem to be keeping up or who consistently lose attention. This could be due to not having the background to understand the material, to something going on in their lives outside of the classroom, or even to losing confidence in their capacity to learn the content. When a teacher observes a student struggling in class, his or her response will depend on that teacher's own capacity and on the resources available in the school. If initial adjustments to the

\footnotetext{
${ }^{41}$ For effects of two-way bilingual education, see for example, Marian et al. (2013).

${ }^{42}$ For a definition and description of RTI, see the RTI Action Network website, http://www.rtinetwork.org/learn/what/whatisrti

${ }^{43}$ One approach to developing a truly inclusive first-tier instructional approach is to follow the principles of Universal Design for Learning (UDL). According to its creators, UDL "drew upon neuroscience and education research, and leveraged the flexibility of digital technology to design learning environments that from the outset offered options for diverse learner needs." For a detailed discussion of the variability of learners and the UDL approach, see Meyer et al. (2014).
} 
core instructional program (Tier 1) don't have an effect, more intensive intervention may be necessary. For example, a possible second-tier approach for students having trouble learning to read may be remediation by a tutor such as a Reading Recovery specialist. ${ }^{44}$ The degree of intensity is an important decision, as is the nature of the intervention. For students who have lost (or never had) confidence in their capacity, one of the strategies suggested by Carol Dweck (2006) in her Mindset research might be appropriate. ${ }^{45}$ Nationally, approximately $10-15 \%$ of students may require the second-tier interventions to supplement the regular instructional program. These numbers may well be higher in high-poverty schools.

The third tier of intervention is more intensive and responds to a continuing problem that could not be effectively addressed through other interventions within the regular classroom. It could entail a meeting to consider providing the student with special services under a federal 504 plan or even an individualized educational plan (IEP). ${ }^{46}$ Prior to that, however, there should be a set of second-tier services and appropriate support and analysis of the student's problems.

\section{Attending to Transition Points}

RTI provides a framework for intervention at all levels of schooling. Without careful and well-implemented interventions, too many students, especially those from lowincome families, will fall through the cracks, lose confidence about how they are doing in school, and try to avoid notice until they are old enough to leave school. The problems can come at any time during a student's educational career.

Yet there are predictable times during a student's voyage through school when problems are both more likely and particularly consequential for future success. ${ }^{47}$ Often these critical points occur during major transitions in a student's schooling and are especially problematic for traditionally underserved students. For many of these transition points, there may not be an individual teacher or other adult in a position to be aware of problems; targeted support systems to help clear students' paths during these times are thus critical.

\footnotetext{
${ }^{44}$ For general information on Reading Recovery, see the Reading Recovery Council website http:// readingrecovery.org/reading-recovery/teaching-children/basic-facts. For evaluation findings, see Consortium for Policy Research in Education (2013).

${ }^{45}$ The studies and interventions used by Carol Dweck seek to change students' mindset from believing that their intelligence is fixed and determines their school performance to one where they believe that if they work harder, study more, and pay greater attention in school their grades would increase. For a description, see Dweck (2012).

${ }^{46}$ For detailed description and delineation of differences between 504 plans and an IEP, see Understood Team, The Difference between IEPs and 504 Plans, http://www.ncld.org/studentsdisabilities/iep-504-plan

${ }^{47}$ See Kieffer et al. (2011). For a consideration of transition from middle school to high school, see Kathy Christie and Kyle Zinth, "Ensuring Successful Student Transitions from the Middle Grades to High School," http://www.adlit.org/article/32116/. Also see Neild (2009).
} 
The first major transition occurs in kindergarten. A child who comes into kindergarten having had rich language experiences, having developed self-regulatory behaviors, liking to count, and able to share will do well in school. Note that SEL skills are particularly important. Alternatively, if the child missed the opportunities to build these competencies - for example, if he or she never had preschool experience or opportunity to develop these skills in the home- the child may struggle. A child lacking these experiences and skills may not show clear indications for a while, but signs of insecurity, frustration, difficult classroom behavior, and data from diagnostic instruments should alert teachers. Students from low-income homes are disproportionately likely to enter school with some of these challenges as more than half do not attend preschool. In some schools a teacher may be overwhelmed and unable to adequately treat every student, but a school that uses an SEL model and systematically practices a form of RTI is likely to be ready for this. In effective kindergartens in high-poverty schools, students take diagnostic assessments of their language and other skills very early, and there is a regular and systematic approach to working with the students and possibly their parents to catch up. In many chaotic elementary schools with new or poorly trained kindergarten teachers, however, few such supports exist. ${ }^{48}$

A second major transition point occurs toward the end of third grade. The expectation in American schools is that by this time students will be comfortable reading appropriate texts, gaining information from them, and demonstrating their comprehension of the material they have read. The shorthand for this expectation is that prior to fourth grade students learn to read; from fourth grade on, students read to learn. What this means instructionally is that in many schools the intense focus on learning to read subsides in fourth grade, and students who have not mastered comprehension skills and strategies will likely struggle to keep up. We see two implications of this pattern. First, it is critical that all students receive high-quality reading instruction and rich language experiences prior to fourth grade. Second, for those who haven't, a well-designed RTI second-tier intervention must be available to remedy the gaps.

The moves from elementary to middle and middle to high schools are other major transition points in a student's educational career, as is going from secondary school to a community college, four-year college, or to work. In each of the transitions, the rules and expectations for students change. For example, in the move from elementary to middle school, students must suddenly negotiate the rules and personalities of a half dozen teachers rather than one, the stakes are higher, and the academic demands - including homework - are much greater. Moreover students at this age change physically, and the impact of their social world intensifies, now

\footnotetext{
${ }^{48}$ Large numbers of students with these issues might signal the need for more interventions at home. Nongovernmental organizations such as Home Instruction for Parents of Preschool Youngsters (HIPPY), provide information about alternative interventions or strategies that might be used to provide support to parents and, through them, to students. Organizations such as "Too Small to Fail" provide advice and guidance. See the HIPPY USA website at www.hippyusa.org/ and the Next Generation website at http://thenextgeneration.org/tags/too-small-to-fail
} 
aggravated by social media. These changes may be especially challenging for students who lack support at home and may lead some to decide that school is not worth the effort or not relevant to their lives. In addition, pressures and dangerous alternatives outside school can capture students' attention and provide less constructive kinds of social and emotional support. Having a trusted adult at school or in the community, with whom a student may honestly and openly discuss problems and plans, can help individual students navigate both the demands of school and the potholes of adolescent development. Unfortunately, such role models and trusting relationships with adults are too often lacking in schools, especially for low-income students of color. Small schools and learning communities, where students and teachers can get to know one another; advisory classes; and special initiatives like the Manhood Development Program in Oakland, CA, are examples of strategies that districts and schools have employed to help build the needed connections between students and caring adults.

There are also consequential decisions about courses that students and their teachers need to make in seventh, eighth and ninth grades to prepare for high school. If a student misses taking Algebra 1 by ninth grade, for example, the consequences are often considerable. Because of master-schedule problems in secondary schools, this can result in students being left out of the math sequence and out of the academic track. Some studies indicate that low-income and immigrant students without counselors or trusted advisors do not realize the importance of this sort of planning.

Ninth grade appears to be a particularly important year for academic intervention (Allensworth and Easton 2007). For this reason, some districts and states are implementing "early warning indicator" systems to identify ninth-graders who are at risk for dropping out. Based on research by the Consortium on Chicago School Research, for example, Chicago Public Schools adopted a "freshman year on-track indicator" and began providing schools with real time data about which ninth-graders were and were not on track for graduation as well as guidance on how to help students get back on track. A new report on this initiative indicates that Chicago's on-track rate rose 25 percentage points from 2007 to 2013, and that this increase occurred across all racial/ethnic groups, genders, and incoming achievement levels. What is more, the improvements were largely sustained in later grades, contributing to higher grades and increased graduation rates down the road (Roderick et al. 2014).

Another increasingly popular approach to improving graduation rates and better preparing students for transition to adulthood is to provide multiple pathways to graduation. All pathways are intended to prepare students for postsecondary opportunities, but they are designed to tap into varying student interests and real world realities (Symonds et al. 2011). More and more districts and schools are thus beginning to offer sequences of courses focused on occupational domains or issues in today's society. A student in one pathway might focus on health care; his or her math, science, and literature courses would reflect this theme. Another student might follow a pathway focused on the environment or the building trades. These pathways provide relevance and might also include opportunities for students to apprentice in their areas of interest (see Chap. 10). In many settings, the high schools 
are connected to community colleges, which provide additional courses with the same pathway focus once the students have graduated from high school. Earlycollege high school programs make such connections even before graduation and have demonstrated success in rigorous studies of their effects for low-income students (Berger et al. 2010).

Finally on the transition theme, many students who graduate from secondary school and go on to college (including community colleges) find out they need remedial courses before they can take courses for credit. Nationally, the figure for such students is approximately $60 \%$ of the incoming cohort (Southern Regional Education Board 2010). Many are low income or ELL. Most fail to pass the required exams and drop out before even passing one credit-bearing course. This pattern is costly and devastating for many low-income students and for local regions and whole states as well. Exemplars of successful approaches include that of El Paso, Texas, where the local districts, community colleges, and local university have worked together for years to ensure equitable access and success. Another approach is to focus on improving student success in gatekeeper courses within the community colleges. Recent work of the Carnegie Foundation for the Advancement of Teaching, for example, has produced a powerful technology-supported intervention for students in developmental mathematics courses in community colleges. Given these alternatives, the task may now be less a conceptual challenge than the political problem of making serious changes in the colleges (Yamada 2014).

Taken together these leverage points provide a crude template for schools and districts committed to not allowing any student to fail.

\section{Beyond School: Connecting Schools with Services and Institutions in the Community}

As we noted earlier, the entire environment in which students live influences their development and success in school. We have emphasized the importance of good medical care, healthy food, a supportive and language-rich environment, and at least a year of preschool as important preparation for academic learning. These conditions and other opportunities outside of school continue to be important determinants of students' success and resilience in school. While we have described the negative side of some of the poorest communities and neighborhoods, there are often NGOs, churches, and government agencies available and capable of providing support and services for the students during those 4500 waking hours outside of school.

Connecting schools with other systems is not a new idea in the U.S. In the early 1900s, John Dewey, Jane Addams, and others argued for schools in the cities to be the center of a neighborhood's life by being the center and provider for social life and services. Later on, the Mott family, working through their foundation in Michigan, supported schools that served multiple services, a model and philosophy 
that spread through many parts of the country. In 1974, amendments to ESEA included the creation of a small grants program for Community Schools that enabled funds to support model community schools directly as well as state activities in support of community education. This program was ended in the consolidation of programs in 1982, but the federal government came back in 1997 to support twenty-first century After Schools programs and, more recently, twenty-first century Learning Centers.

In 2014, the Coalition for Community Schools held a national forum with 1400 participants. The coalition's concept is broad and includes making full use of the school (open all of the time) for the community, health services, and social services. This concept is often called the full-service community school program, and it has schools all across the nation. Using the school as a hub, a community school organization coordinates education and social service organizations all through the neighborhood, including businesses, colleges, adult education, family support activities, and other NGOs.

Another strong organization in this area is Integrated Student Supports (ISS), which is a school-based approach to promoting students' academic success by providing academic and nonacademic support services including tutoring, mentoring, linking students to health care and families to counseling, education, food banks, and employment. Integration around individual student needs is the key factor.

Perhaps the best-known example of the systemic community-based approachand surely one of the most expensive- has been the Harlem Children's Zone (HCZ), which takes up a 100-block area in Harlem's largely African-American area of New York City. HCZ connects students and their families with the entire panoply of social and educational services; where services have not existed, the organization has raised the resources to create them. HCZ has even created its own small network of schools that admit interested students through a lottery process. ${ }^{49}$ Recently the federal government launched a program of competitive grants called Promise Neighborhoods that is modeled after the Harlem Children's Zone; in the last four years, over 40 districts in the nation have received Promise Neighborhood grants. ${ }^{50}$

Other settings — such as Long Beach and El Paso-have focused on developing strong collaborations between their school systems and the local community colleges and public universities, particularly those engaged in teacher preparation and development. In Oakland, the schools host farmers' markets in neighborhoods with no grocery stores. And in Silicon Valley, the John Gardner Center at Stanford works with a number of communities to link data from local social service agencies and community-based organizations to identify patterns and gaps and to ensure that students needing service have access to what they need.

\footnotetext{
${ }^{49}$ See Wikipedia (http://en.wikipedia.org/wiki/Harlem_Children's_Zone) for a description and citations on the Harlem Children's Zone. Also, for a recent analysis that suggests that the schools in the Children's Zone are responsible for observed academic gains, see Dobbie and Fryer (2011). ${ }^{50}$ For information about the Promise Neighborhood awards, see the U.S. Department of Education website at http://www2.ed.gov/programs/promiseneighborhoods/awards.html
} 
Studies of these and similar efforts generally find small positive or insignificant effects on school achievement. But the afterschool activities are often not well coordinated with the instruction that students receive during the regular school day. Some interventions-such as those that connect children with food and medical service, young adolescents with counseling, and schools with teacher training institutions - have a high degree of face validity, even if they do not have evidence of a direct impact on student achievement. An integration of the Gardner Center's data strategy with health, nutrition, and some basic academic and social support services would provide a neighborhood or community with what seems to be the critical core interventions of all of these general programs and a mechanism to make sure the system is working with the students who most need assistance.

The bottom line is that there is a lot of energy around these issues across the nation. The systemic nature of the interventions and the urgency of the need for the populations they serve make a compelling case for their existence in every highpoverty neighborhood. It appears to us to be very unlikely that the achievement gaps can be closed substantially without interventions that mobilize neighborhoods that lack resources for their children around a set of strategies that engage the communitybased organizations, the local governments, and the private sector.

\section{Getting From Here to There: The Problem of Change at Scale}

This vision of a more equitable system addresses the key shortcomings of past and current efforts to reduce achievement and opportunity gaps. It provides a framework to promote and extend system coherence, embeds improvement efforts in specific systemic contexts, balances whole system change with targeted interventions for underserved and struggling students, and recognizes the importance of connecting schools with other organizations and agencies affecting children and their families.

But envisioning what might be a more effective system is one thing; moving in this direction and doing it at scale is something else. For this discussion we incorporate an observation from decades of implementation research: Effecting change requires a context-appropriate balance of pressure and support-pressure to engender action and support to increase its effectiveness (McLaughlin 1987). This observation about organizational and system-level change is consistent with theory and research on individual performance, which is generally defined as an interactive function of individual motivation, ability, and situation (Rowan 1996).

We see three potential sources of pressure and support to move educational systems in the direction we have suggested: governmental and administrative policy at the federal, state, and local levels; professional networks and norms; and community and stakeholder constituencies. 


\section{Designing Governmental Policy to Motivate and Support Improvement and Equity}

Governmental and administrative policy at the federal, state, and local levels has been the predominant source of external pressure and support for educational change in the U.S.- particularly with regard to equalizing opportunities for poor students, students of color, and English learners. Over the past six decades, this source has generally become more centralized, with states providing an increased portion of school funding (and demanding greater accountability for how those funds are spent) and the federal government taking more of a role in not only enforcing equality but also influencing the core direction of schooling. With respect to the balance between pressure and support, the scales at these two levels have recently tipped toward pressure and compliance, though requirements are often tied to categorical funding streams that wear the guise of inducements and fiscal support rather than blanket mandates.

We have noted earlier how this emphasis on compliance can actually thwart improvement and lead to unintended negative consequences for underserved students, even when they are the intended beneficiaries. In addition, because policy is made at all levels of the system, schools are frequently confronted with a panoply of conflicting rules, overlapping programs, and fragmented directions that divert attention and prevent real change.

To move toward a system that facilitates continuous improvement where it matters most-in the schools-will require a reconceptualization of the roles of the three levels of government and a rebalancing of emphasis between pressure and support, with greater attention going to providing long-term support for improvement than has been the case in recent years. At the core of this reconceptualization are the twin principles of (a) common commitment at all levels to the goals of equal opportunity, achievement, and attainment, and (b) governmental restraint and focus to achieve these goals. By restraint we mean that each level of government must fully consider the likely tradeoffs and potential unintended consequences before it creates new rules, strong incentives, and/or legislation based on ideology, politics, or even some evidence of effectiveness. The question must be, will the proposed action actually motivate and support greater equity and higher quality, or will it disrupt ongoing improvement processes and stress the schools and the teachers? ${ }^{51}$

A first step for all levels of government on the road to help schools and districts to achieve the improvement and equal opportunity vision is to model the ideas of continuous improvement within their own operations and to reach out to create

\footnotetext{
${ }^{51}$ For example, when Congress passed the No Child Left Behind Act in 2001, it put in place a set of accountability provisions that no state could feasibly achieve (primarily that $100 \%$ of all students would be proficient on the state standards-aligned assessments by 2014). The Obama administration has provided waivers from many of these provisions, thus giving states an alternative to designating all of their schools as failing. But the department predicated these waivers on state actions - such as using student test scores to evaluate teachers- that were not relevant to the substance and purpose of the waiver.
} 
more collaborative environments with other levels of government and with other sectors that influence the quality and equality of educational opportunity. This will not be an easy task for bureaucracies that have been stove-piped and focused on regulating their clients rather than supporting them in their improvement efforts, but there are examples of some states that have been moving in this direction. At the federal level, the task will be even harder, given the current level of political polarization.

Assuming that reorienting the federal and state systems toward improvement is possible, we suggest below that each level of government has a distinct and important role to play in motivating and supporting movement toward both high-quality systems and equal opportunity.

\section{Federal Role and Policy}

As the 10th Amendment to the Constitution implies, the basic responsibilities and practices of delivering education are left to the states and districts. And, as the 14th Amendment provides, the federal government has a responsibility to protect and support when needed those who require assistance to receive equal opportunity.

Following from these constitutional provisions, a simple test for suggesting what the federal government should — and should not-do in K-12 education is to apply two criteria:

- Does the activity protect or directly support the U.S. constitutional and legislated rights of schoolchildren to receive equal opportunity to a high quality education?

- Does the activity apply to the entire nation and is it more efficiently and effectively delivered by the federal government than it would be by states and districts?

Implementing these criteria would reduce the current portfolio of the U.S. Department of Education and clarify its role around a more highly focused set of responsibilities. The reasons for such a reduction include the great diversity of U.S. students and school environments; the complexity of effective teaching and school management; and the all too real danger of ideology, politics, and regulatory zeal overriding useful evidence within administrations and the Congress. We suggest instead a federal role that works to ensure equity and provides resources but eschews the one-size-fits-all prescription of education practice to states, districts, and schools. This view of the federal role calls for increasing the resources and capacities for support of the programs and policies that directly influence equal educational opportunity.

The activities of our proposed new role may be organized into four groups: protecting and supporting the rights of all students to equal educational opportunity; ensuring equal opportunity for specific groups of students protected under federal law; providing financial resources to equalize educational opportunity for all 
students; and supporting research, innovation, data about the health of the system and resources for improvement.

\section{Protecting and Supporting the Rights of All Students to Equal Opportunity}

The U.S. Office of Civil Rights (OCR) in the Department of Education has the critical function of enforcing civil rights laws affecting educational opportunity-such as the Civil Rights Act of 1964, the various desegregation decisions starting with Brown v. Board, Title IX, and Section 504 of the Disabilities Act. To achieve its mission, OCR balances the roles of enforcer/regulator with providing support to districts and schools to promote greater equity. Both approaches-reflecting the "pressure and support" functions mentioned above-are now part of the office's repertoire. As the climate of education reform changes to improvement rather than adherence to regulations, we suggest greater emphasis be placed on the support approach. This change in direction might require more resources. ${ }^{52}$

\section{Ensuring Equal Opportunity for Students Protected Under Federal Law}

Federal programs to support specifically protected groups of students include the Education for all Handicapped Act (EHA); Title III of ESEA, which supports the efforts to improve the teaching and learning of students whose native language is not English ${ }^{53}$; and the two programs for Native Americans, one in the Department of Education and the other in the Department of the Interior. ${ }^{54}$ These programs differ dramatically in size, delivery strategy, and level of financial appropriation. Unfortunately, because legislative and regulatory environments tend to change slowly and protect vested interests, the programs do not necessarily reflect our new understanding of student learning and the opportunities that have appeared because of new emphases on innovation and strategies for improvement. An important step for each might be to have outside groups of experts and stakeholders carry out thorough and sustained (five-year) studies on how well these programs are working and to recommend changes.

\footnotetext{
${ }^{52} \mathrm{See}$ OCR website at http://www2.ed.gov/about/offices/list/ocr/index.html.

${ }^{53}$ Title III of ESEA, intended to support ELLs, should be substantially modified and retained as a symbol and a vehicle for capacity building and innovation. The past decade has provided a great deal of new research on approaches to teaching ELL students. We have now considerable knowledge about dual immersion and other approaches to bilingual education that suggest that students derive added benefits from learning two languages without losing effectiveness in either. The current instantiation of Title III limits the opportunities for states, districts, and schools to apply this new information in a systematic way and should be changed.

${ }^{54}$ Title XI Education Amendments of 1972 contains an anti-discrimination provision that protects women. There is no specific education program - the Office of Civil Rights in the Department of Education administers the provision.
} 


\section{Eliminating Resource Inequities-Title I and New Strategies}

Title I of ESEA provides funds to high-poverty schools beyond the base of resources provided by state and local funding. The highest poverty schools receive funds to improve the entire school ("school-wide" schools). Less-high-poverty schools receive funds on the basis of number of students on free and reduced price lunch and then use these funds to help low-achieving students (targeted assistance schools). Title I is the best known and largest of the programs that serve the goal of equal opportunity. It has been the object of much political attention, partly because it provides a large amount of money targeted to poor and low-scoring students and partly because the Title I law carries requirements that all states must have academic standards and assessments and administer a federal accountability system to meet the requirements for receiving Title I funds. We propose to curtail the federal accountability provisions in the current version of Title I (NCLB) to include only two elements: reporting of disaggregated results by subgroups, which would continue to be a gauge of equality of opportunity, and a requirement that each state develop a system of accountability appropriate to its context that includes measures to motivate and support improvement and a reduction of achievement, attainment, and opportunity gaps.

The core and historical purpose of Title I would remain. The funds for Title I should be increased and more highly targeted toward high-poverty schools than they are now (over half the schools and almost all of the districts in the nation receive Title I funds), and many of the legislative and regulatory requirements on the specific uses of the funds should be eliminated. The comparability and supplement-notsupplant provisions should be maintained. In fact, in high-poverty schools, Title I should be able to operate as an accelerator of school reform that supports continuous improvement and interventions targeted to ameliorate specific student challenges as they journey through the school.

Even though Title I is a large program, however, it does not come even close to closing the finance equality gap. Any independent observer of educational opportunity in the U.S. would see three glaring and generally ignored sources of gross disparities of resources that favor the well-to-do in our nation. In the initial section of this chapter we pointed out the great differences in wealth and in the resources available to students among the states, among districts within states, and among schools within districts; as a nation, we tend to turn a blind eye toward these disparities. The only entity available to help reduce state differences in resources for public education is the federal government. Great variation of resources among districts within states would logically be a problem to be solved by states; again logically, the within-district, among-schools disparities would be remedied by the districts. However, in this section of the paper we opt to address all three levels of resource inequality. Our reason is that the federal government could play a substantial role in accomplishing progress toward equality in all three of the areas: among states, within states, and within districts. This focus would call for new activities and resources from the Department of Education. 
A serious move toward equalizing resources among states, controlling for effort and wealth, would accelerate equal opportunity across the nation for many lowincome students of all races. A goal might be to bring all states to at least the 50th percentile of the current average per-pupil expenditure among states by 2020. This would require new resources from the federal government, which should be partially matched by states. Particularly in the South, many states lack the financial resources and infrastructure to provide the money to support high quality and effective K-12 schools for all of their schoolchildren. ${ }^{55}$

Meeting the within-state (among district) variation in resource allocation is a somewhat different problem. Attaining equalization among districts should be part of the states' commitment to equal opportunity. Here the federal government might figure out how to motivate state efforts to adopt something like a weighted pupil formula.

The third leg of this fiscal equity stool would be to address within-district inequalities among schools. Here the federal government might take an immediate and powerful step. This approach would require a subtle but significant change to the comparability provision in Title I of the ESEA, a provision that requires the resources available to the Title I schools within a district to be comparable on average with the resources available to non-Title I schools. In the current provision, the resources are defined as "services," such as number of teachers. Because schools with large populations of students from low-income families often have younger and less experienced teachers (due to teachers moving to other schools and to teacher turnover), the total amount paid to teachers, and thus the total expenditures in these schools, are often less than in schools with more affluent populations. We suggest that the comparability provision should be changed to require districts to equalize actual expenditures per pupil instead of "services." A study by the Department of Education found that such a change in regulation could "bring a substantial increase in funding for low-spending, high-need schools" (Stullich 2011, 1). These extra funds would be used to improve the quality of the school, for example, by lowering class size or having reading specialists or counselors.

We are not naïve about the possibilities of enacting any of these three finance proposals. In a Congress where tax cuts are dominant, the idea of investing in the education of students in states other than the congressman's own state does not seem likely to find many advocates. And, even the third proposal, to alter the comparability provision in Title I, has been proposed many times and rejected, with some major education groups leading the opposition. Yet, these three actions, by themselves, would alter the calculus of inequality in the country. They would create huge new opportunities for millions of children and could even engender trust in the public that the rhetoric of equal opportunity is real.

\footnotetext{
${ }^{55}$ See Houck and DeBray (Forthcoming) for a thoughtful discussion of how the federal government might stimulate these equalization reforms.
} 


\section{Supporting Research, Innovation, and Data for Improvement}

The Department of Education should also continue to carry out research and data collection and analysis, focused on improving teaching and learning and on innovation in areas such as technology. As a goal, the department's research efforts should move more toward theoretically driven efforts that carefully aggregate knowledge to increase our understanding of key issues in developing an effective education system for all students. The research results and data from government-funded research should all be as openly available as possible through a Creative Commons license to allow all researchers access to the new knowledge and for those interested to be able to use the data to replicate and possibly illuminate the original results. ${ }^{56}$ Explorations into innovative ways of using new knowledge and opportunities made possible with technology should be a significant second focus of the research. A third area of activity involves the collection and analysis of data on the status of the system, which has been a function of the department since its original instantiation in 1867. Such data collection requires constant attention and improvement to provide the best possible information and data for researchers, policy makers, and the public to use.

This discussion of a more limited and focused role of the federal government implies a need to eliminate or consolidate a substantial number of current federal programs while refocusing others. We believe that such a consolidation should focus on two purposes. The first would be to support overall continuous improvement strategies in districts and schools; the second would be to kick-start withindistrict and among-district equalization strategies.

\section{Role of State Governments to Ensure Quality and Opportunity}

The basic roles of the states, granted to them under the 10th Amendment and built into their state constitutions and legislation, include responsibilities for all aspects of the education system from governance to finance to curriculum to supporting, enhancing, and monitoring quality education for all public school students in the state. $^{57}$

\footnotetext{
${ }^{56}$ Preservation of anonymity and protection of human subjects can be more complex with qualitative data than with large-scale survey or assessment data, and demands for transparency and replication must be tempered by the feasibility of making these data available without jeopardizing the anonymity of particular individuals. See www.CreativeCommons.org for information about the Creative Commons licenses.

${ }^{57}$ States differ substantially in their political and administrative structures with respect to education. In some states, the state department of education exercises the primary leadership, policy, and administrative functions; in other states, the governor and state board of education have the primary leadership and policy roles. We refer to the state as a whole in this chapter, irrespective of which particular agency or branch of state government carries out a given function. Of course, similar variation in governance structure occurs at the local level; in some districts, the mayor has
} 
In general, states delegate many of their responsibilities to local districts through legislation and their constitutions. They maintain full control of the responsibilities to actively build and monitor a legislative and regulatory framework that guides the districts as they implement much of the remainder of the responsibilities. States are responsible for decisions about common statewide content and performance standards, assessments, accountability, data collection requirements, and regulations about certifying and training teachers. They also manage and provide oversight for federal and state categorical programs. The financing of public education is generally shared, but state legislation or constitutions determine the framework for the finance system. Local districts manage the fundamental tasks of teaching and exercising the day-to-day responsibilities for educating the youth.

An unfortunate fact is that states and local governments and schools have implicitly or explicitly discriminated against low-income individuals and those of color in schools for well over a century. We have documented gaps between rich and poor schools and districts in finance, in prepared teachers, and in other materials in schools that provide clear evidence of these practices.

In order to move resolutely toward the goal of equal opportunity for all, states must develop, maintain and improve well-functioning education systems that support continuous improvement and high quality teaching and learning for all schools and students throughout the state. If the system is dysfunctional, the least advantaged among us will suffer the greatest.

We suggest three broad roles for the state in motivating and supporting educational quality and opportunity for all students:

- Establish a vision and set of priorities for educational improvement in the statethat is, to set the direction

- Provide resources and infrastructure to support continuous improvement toward this vision

- Establish a fair accountability system that stimulates action and tracks progress_-particularly progress towards equity

\section{Setting the Direction: State Standards and Priorities}

We have already noted that robust and challenging standards for what students should know and be able to do can serve to define equity goals and guide continuous improvement toward those goals. Adoption and support for district implementation of new generation standards and assessments and establishing aligned policies to help guide curriculum development, educator training and accountability is an important role for states. As states transition to new standards and assessments and work to make the necessary changes in other parts of the system, it is especially crucial for them to pay attention to low-income districts, schools, and regions of the

substantial authority while in most others the superintendent and the local board are in charge. Again, we focus on the level of the system in general rather than on the roles of specific actors. 
state that have fewer resources than others to carry out implementation. Analysis of statewide data can help states set priorities for moving forward to ensure that all students have access to the standards.

But standards and priorities are only one step toward setting direction for the state. Equally important is ensuring consistency in the signals to local districts and schools through consistent leadership and sustained commitment to improvement. This has been and continues to be a major challenge in the majority of states. All too often, state leaders do not have a deep understanding of the nature of the problems; state bureaucracies are locked into patterns that are directive and punitive rather than supportive; and lobby groups work to maintain current practices, often by guiding the votes of legislators and the behavior of the administrators. These practices will not change quickly, but they can be ameliorated over time. Though not yet fully successful, leaders in states such as Massachusetts, Connecticut, Minnesota, Texas, and now California have made substantial progress. The key is sustaining the work over time. One- or two-term leadership is not enough; change of the sort we describe here takes a decade or more to embed itself into the fabric of the system. The task is not easy-the commitment to sustain a policy direction that is based on continuous improvement and equal opportunity is difficult to keep up without succumbing to the siren call of "magic bullets." But it is necessary. And we suspect that strategic mobilization within the profession and among community stakeholders will be necessary to reach a common vision and ensure that state governments actually stay the course (see below).

Providing Resources and Infrastructure to Support Continuous Improvement and Equity

Standards and commitments will, of course, be meaningless without action to back them up. One of the most important roles for states to play is to provide the resources and build the infrastructure necessary to support local capacity for improvement and equity. We highlight three arenas in which state resources and infrastructure are most important: human capital, finance, and data.

\section{A Strong Professional Workforce}

Many states face serious human capital issues that hold back improvement and perpetuate inequity. These include teacher shortages, inadequate pre-service training, limited capacity of current teachers for teaching the new content or teaching all students, and a limited supply of well-trained principals. Moreover, the challenge of creating and maintaining a continuous improvement environment and implementing a thoughtful intervention system requires changes in the responsibilities of educators throughout the system. Education systems cannot provide high-quality schooling for all students without high-quality education professionals. The costs of 
building professional capacity may seem high, but the cost for not doing so is far higher.

States are in a critical position to ensure all students have access to high quality and effective school personnel. A first step is to support the recruitment of talented and interested people to enter the profession. Currently many young people do not see teaching as a desirable option because of a political atmosphere that seems to target teachers, relatively low pay, perceived job insecurity due to uncertain budgets and high-stakes accountability, and the poor reputation of teacher training programs. ${ }^{58}$ State political leaders can join with university presidents and others to use the bully pulpit and incentives to upgrade the quality of pre-service training and increase the attractiveness of teaching.

A second step is to create the conditions for teachers and principals to grow in their jobs. High-quality mentoring in the first two years shows solid effects, and we have learned much in the past two decades about designing effective ongoing professional learning. A substantial new body of evidence, for example, indicates that both human and social capital are critical to the development of high-quality teachers and schools (Hargreaves and Fullan 2012). States can provide support to build a strong statewide infrastructure for professional development, including the creation of networks among teachers, schools, and districts. This is particularly important for low capacity and isolated regions of the state to ensure equity.

Finally, a critical role for the state is to ensure equitable access for all children to high-quality teachers. Specific tenure and seniority provisions in some state laws may exacerbate the low quality and ongoing churn of educators in schools and districts serving high needs students. The recent Vergara lawsuit in California was predicated on the idea that there is a set of laws and practices that systematically ensure that poor children, on average, have the least qualified and experienced teachers. ${ }^{59}$ Whatever one's position is on the lawsuit per se, that the state has a role in ensuring equitable distribution of high-quality teachers should be undeniable. A first step would be to review potential disparate impact of policies currently in place and to improve working conditions in high-poverty schools.

The implications of not meeting these challenges will fall most heavily on the students most in need. The well-to-do communities of the nation will not suffer from the failures to meet these human capital challenges; they will get the first choices in a tight teacher market. It is the children in the central cities, the small, poor rural communities, and in other places where there are large populations of the lowincome families that will suffer.

\footnotetext{
${ }^{58}$ See, for example, Jill Tucker, "Bay Area Schools Scramble for Qualified Teachers amid Shortage, SFGate, October 12, 2014, http://www.sfgate.com/education/article/Bay-Area-schools-scramblefor-qualified-teachers-5818410.php

${ }^{59}$ See the Vergara v. California entry in Wikipedia for background information on the suit, the specific state statutes involved, and additional citations. http://en.wikipedia.org/wiki/ Vergara_v._California
} 


\section{Adequate and Fair Funding}

We have already suggested something concrete the state governments might do to ensure finance equality across the districts state-legislate and implement a weighted pupil formula or an equivalent approach. ${ }^{60}$ This action can be taken in the current environment, as demonstrated by California. It will require new revenue and time, but as we suggested earlier, the change could be spread over time and partially supported by the federal government. States should also seek ways to stimulate within-district equalization. Each of these actions would very positively alter the current unequal resource allocation problems in many states.

A fair and equitable finance system also must face the challenges of providing extra support for the groups of high-risk students that do not fit into the categories of the protected because of race or poverty. Special treatment is necessary for four additional groups of at-risk students that together may constitute up to 4-6\% of all of the nation's children in school: foster children (400,000 in the U.S.), children with incarcerated parents (2.7 million), homeless children (500,000 in any given year), and children/youth who suffer from a serious mental disorder (estimated four million nationally, many of whom are not served by special education) ${ }^{61}$

\section{Effective Data Infrastructure}

We have already considered the importance of data to continuous improvement; we believe the state is in the best position to ensure that the data infrastructure is sufficiently robust and adaptable. Beyond this the state must be able to point to examples of effective use of data as integral to continuous improvement and as offering a methodology for use throughout all of their districts and schools. This is particularly

\footnotetext{
${ }^{60} \mathrm{We}$ recognize the difficulty of creating weighted pupil formulas in states where high percentages of school funding comes from local sources.

${ }^{61}$ Embedded in the federal education code are programs directed at some of these students, but even where there is a targeted program, the federal contribution to the support of the students is de minimis. For the federal homeless program, for example, the average support to a school for a homeless child is roughly $\$ 40$ per year. Many states have similarly small programs for different groups of students. Others are unserved. Their in-school and out-of-school lives are chaotic and depressing, and each of these groups has a very high dropout rate. When they enter their teenage years, far too many suffer from drug or alcohol addiction and many of the males are eventually incarcerated. Even considering the overlaps among categories, the sum of students in these groups in any given year is likely between 2 and 3 million, or roughly 4-6\% of the public school children in the nation. For details on specific groups of these children, see the following sites: http://www.endhomelessness.org/ and http://www.mercurynews.com/breaking-news/ci_ 24294107/fears-another-lost-generation-youth-homeless-numbers-rising (homeless youth); http:// www.osborneny.org/images/uploads/printMedia/Initiative\%20CIP\%20Stats_Fact\%20Sheet.pdf; http://www.acf.hhs.gov/programs/cb/faq/foster-care4; and http://www.childtrends.org/?indicators= foster-care (foster youth); and http://www2.nami.org/Template.cfm?Section=federal_and_state_ policy_legislation\&template $=/$ ContentManagement $/$ ContentDisplay.cfm $\&$ ContentID $=43804$ (youth with mental disabilities).
} 
important in low-capacity regions and districts that cannot do all the needed data work on their own.

\section{Establishing an Accountability System that Supports Improvement}

We expect that in the next few years, the locus of education accountability will largely shift from the federal to the state governments. Although they have shared the responsibility in law, the federal government has dominated since NCLB was passed in 2002. Over the past 25 years, the concept of accountability has driven a lot of positive and negative activity in schools and districts. For much of this time, accountability has been a one-way street. Schools and teachers have been held accountable for performance goals set by the federal government and states have been required to meet these goals to avoid being penalized. Only in extreme situations did districts face consequences for failing to meet performance goals, and never for failing to provide sufficient resources or assistance to their low-performing schools. The idea of reciprocity was not part of the mix.

In reciprocal accountability, the entities that hold schools and teachers accountable and control the provision of resources should share in the responsibility for the quality of the practices and student outcomes. Few would argue this premise. Yet while we acknowledge and document that many schools that are predominantly poor and African-American or Hispanic do not receive even the same level of resources as schools of the well-to-do (much less the level of resources they need), we still hold them to the same standards as the largely well-to-do schools.

For a high-stakes assessment to be fair, all students should have equitable opportunities and resources (Messick 1989). Clear and understandable reviews of the resource quality of a school and district should be conducted regularly. States should review their internal frameworks for assessing quality to make reasoned judgments about the opportunities available in districts and schools. Performance and quality measures for schools and districts should be transparent and reported.

The discussions about accountability are almost all focused on the details: How many years of testing should there be? Should the goals be set for 3, 5, or 10 years? Should we require penalties? As the states take over the responsibility to design and manage their accountability system, state leaders should first step back and decide what they want to accomplish. If they want a valid and effective system, they first need to address the glaring issues of inequality. They might also establish goals as well as monitor and provide support to districts and schools that have trouble maintaining progress. Reasonable long-term state goals might be high-quality education for all and equal outcomes for all subgroups of students. An overall short-term goal would be steady progress on the quality and outcome indicators by schools, districts and the state. 


\section{District Responsibilities}

Of all the levels of governance, local districts have the most direct influence on what happens in schools. They are responsible for recruiting, assigning and supporting teachers; setting instructional policy; ensuring appropriate and efficient management of schools; allocating resources; and establishing an infrastructure to support system learning and ensure equity. The approaches that districts take to accomplishing these tasks will vary depending on the students they serve and the conditions in which they operate. There are 13,500 public school districts and 95,000 schools in the United States. Almost two-thirds of districts have fewer than 1500 students.

Among this diverse population of local systems are varying capacities and challenges. Most small districts, for example, rely on regional or county offices of education to provide expertise about technology, teacher recruitment, special education, and other federal and state programs and policies. Traditionally the quality of reform implementation will depend on the capacity of the state and regional entities to reach out and provide support. Right now the support role of these organizations often conflicts with their regulatory responsibilities, which often take precedence. We suggest that the balance needs to shift more toward improvement and support at all levels, particularly the local level, where it is likely to make the most difference. If the responsibilities of the federal government and states shifted more toward improvement in the ways we have suggested, the local and regional organizations could focus more effectively on improvement as well. This would be beneficial both to smaller, lower-capacity districts and to larger systems with greater capacity that have often been thwarted in efforts to more effectively serve the students by fragmented, compliance-oriented state laws and agencies.

We see four main arenas in which district action can motivate and support both quality and equality. The first concerns districts' role in establishing a culture of continuous improvement focused on the success of all students. We have already described several systems that have demonstrated some success in this regard. These are systems that have established common goals and metrics to measure progress toward attaining those goals. Particularly important is that the metrics include information that allows system and school leaders to identify specific gaps and areas for improvement. Dashboards reflecting these multiple measures can allow district leaders to allocate attention and resources (including human, material, and intellectual resources) to address identified problems of practice. Providing support for cross-school and cross-functional collaboration and learning, in addition to establishing a culture of trust where failure is understood and used as an opportunity for growth, are also part and parcel of such a system.

A second arena in which districts can foster positive change is through the establishment of a systemic approach to equitable resource allocation based on student and school needs. There are various models for more effective within-district allocation, all of which rely on clear alignment between system goals and budgeting processes. Whatever budgeting system a district uses, monitoring the effectiveness of programs and strategies is crucial to ensure that resources flow to more effective strategies and less effective ones are pruned away or revised. 
Of course, the district's most valuable resources are its people, particularly its teachers and administrators. Thus, establishing an effective human capital system that ensures quality and supports continuous learning is perhaps the district's most critical function. Although educator quality is a goal at all levels of the system, districts have particular roles to play at key junctures: recruitment, tenure decisions, and evaluation cycles. Because the pools from which districts and schools recruit staff are primarily local, some districts have even established relationships with local pre-service programs or established their own teacher residency and administrator training programs to ensure that those pools are filled with candidates likely to meet their needs. And once hiring decisions have been made, districts can do a great deal to provide structure, time, and support for coordinated learning within and across schools and to engage teachers and administrators as professionals in their own learning processes. In all these functions, as well as in negotiating contracts, building a strong and productive relationship with the unions is critical and generally beyond the capacity of individual schools.

A final role is to engage the broader public, manage the inevitable politics of American education at the local level, and connect schools and students with other child-related agencies and organizations that can help address students' broader needs. For many larger districts, these reforms would be carried out in intensely political environments. School boards are often steppingstones to higher elected office. Campaigns cost money that needs to be raised from donors. Local boards generally accept state law and regulation-but may greatly influence the implementation of the reforms. Unfortunately school boards in these cities routinely roll over their superintendents every three to five years and seem to be always on the outlook for "magic bullets" that will assuredly and easily raise student achievement. Stability, focus, adaptation, and a continuous strategy and commitment to meeting the needs of all students are a recipe that is only attractive when your constituency is seen to be benefiting.

\section{Increasing Professional Accountability and Support}

Governmental and administrative policy, no matter how well designed, is insufficient to achieve the goals we have described. We see the education profession itself as a needed second source of both pressure and support for improvement. Decades of policy implementation research have demonstrated that teaching is too complex to be effectively governed by bureaucratically defined rules and routines. Teachers not only require specialized knowledge, as do all professionals, but must be able to apply their knowledge and skills in specific contexts (students, content, school setting, etc.) to the benefit of their clients (students). In mature professions, the requisite knowledge is articulated in professionally determined standards of practice, and members of the profession assume responsibility for defining and enforcing those standards. This is professional accountability. 
In earlier work, O’Day (2002, 2008) argued that professional accountability offered a promising complement to policy actions in support of improvement by focusing attention on the core process of instruction, the need for ongoing learning of the adults in the system, and the norms of professional interchange. By professional interchange, we mean placing the needs of the client at the center of professional work, collaborating with other professionals to address those needs, and committing to the improvement of practice as part and parcel of professional responsibility.

Professional accountability is thus closely tied with the more recent concept of professional capital put forward by Andy Hargreaves and Michael Fullan (2012). Defining professional capital as comprising human capital (knowledge and skills), social capital (relationships among professionals and between professionals and other stakeholders), and decisional capital (the ability to make discretionary decisions), these authors use the experience of Ontario and other school systems to argue that professional capital sits at the heart of effective efforts to improve outcomes for students.

Professional accountability/professional capital can motivate and support continuous improvement and equity in education in several ways (O'Day 2008). First, the focus on both instructionally relevant processes and student outcomes sets the stage for improvement cycles in which actions are systematically related to results in an ongoing progression of individual and organizational learning. Second, the emphasis on professional knowledge makes it more likely that educators will be able to posit reasonable hypotheses within those cycles and interpret and act on the information they receive. Third, inculcating norms of professional collaboration will increasingly put educators into situations in which they can benefit from the knowledge and skills of peer; when this collaboration reaches across contexts, it will provide opportunities for educators to challenge their own and each others' existing assumptions about the capabilities of students and effective practices. Fourth, professional accountability expands the incentives for improvement, with particular emphasis on the intrinsic motivators that bring teachers into teaching in the first place - a commitment to students and identity as an educator (O'Day 1996; Finnigan and Gross 2007; McLaughlin and Talbert 2001). Finally, to the extent that the profession's focus on the needs of clients encompasses a commitment to reducing opportunity and outcome disparities, professional accountability can help sustain an equity agenda over time.

We see the emergence of professional learning communities (PLCs) within and across school sites in recent years as a manifestation of the potential power of professional capital and professional accountability. Where they work well-as in Sanger Unified School District in California-PLCs operate as communities of practice (Wenger 2000) in which participants work together to address a shared problem of practice, developing common norms and tools to facilitate the process over time. They follow protocols similar to the Plan-Do-Study-Act cycles in which they identify a problem, plan how to address it, do what they set out to do, study the results — often through examination of assessment data or student work-and then 
act upon this information to refine the next cycle of inquiry and improvement. In Sanger, this process is structured around four key questions:

1. What do we want our students to learn?

2. How will we know when they have learned it?

3. How will we respond when learning has not occurred?

4. How will we respond when learning has already occurred?

Participation in the PLCs is seen as part of what it means to be a teacher in the school or district, and the patterns of professional responsibility and inquiry among teachers are mirrored in communities of principals and of administrators within the central office. In Sanger, PLCs have been the cornerstone of the improvement process since 2004 and have moved this high-poverty, high-English-learner district from being one of the lowest performing in the state to one that has been nationally recognized as a model of exceptional turnaround (David and Talbert 2013). Similar, if somewhat less pronounced, examples of a PLC-based strategy have occurred in districts across the U.S.

Professional associations and networks are also avenues for the development and diffusion of professional norms and practices and can be vehicles for taking the principles of PLCs and continuous improvement to scale across districts and even across states. Organizations like the National Council of Teachers of Mathematics or the California Subject Matter Projects have been significant forces for changing teaching practices and norms and for maintaining relationships among disciplinebased professionals over time. Recently, efforts to implement the Common Core State Standards have become a focal point for the work of many such networks and professional associations, with the commonality of the standards providing the basis for collaboration across contexts. Networks of schools or districts are playing a similar role at the organizational level, providing opportunities for mutual learning and improvement.

The ten CORE districts in California, for example, have developed common metrics and are engaged in mutual learning activities to implement the Common Core State Standards, increase achievement and attainment, and reduce disparities for the over one million students they collectively serve. ${ }^{62}$ Their efforts have become models for others in the state and have helped to inspire similar partnerships among groups of smaller districts focused on shared problems, such as improving instruction and outcomes for California's substantial population of English language learners. It is important to note that while these are formal partnerships across school systems, it is the professional learning and relationships within them that drive the work. It is also important to note, in the context of this volume, that the focus in these efforts is on improving both quality and equality within the educational systems involved.

\footnotetext{
${ }^{62}$ The district partners in CORE include Los Angeles, Long Beach, Garden Grove, Santa Ana, Fresno, Sanger, Clovis, Sacramento City, San Francisco, and Oakland Unified School Districts.
} 


\section{Mobilizing an Engaged Citizenry}

Professional accountability is not enough, however. There have been many examples in recent years of equity-focused reform efforts-even some with fair support among educators - that fell to partisan politics and pushback from a public that didn't understand or agree with the rationale for the changes. Often, public and political support for the status quo is based on deep-seated beliefs about meritocracy, the scarcity of educational goods, and the inability of some children to take advantage of opportunities when offered (Oakes and Lipton 2006). Behind these beliefs sits a power structure that preserves advantages for wealthier and more privileged communities at the expense not only of less privileged communities but also the nation as a whole (Stiglitz 2012). To create and sustain meaningful policies and practices to equalize opportunities for low-income students and students of color requires more than technical solutions and more than an engaged profession. It also requires public constituency and mobilization.

We see this mobilization as necessarily occurring on two levels. One is the coordination of efforts at the "grass tops"- that is through building coalitions among the leaders of the many education stakeholder groups - everyone from higher education institutions to employer groups, parent organizations, advocacy and civil rights groups, and health care and community-based organizations that work with children in other capacities. Political figures and public agency representatives may be a part of these coalitions, but they focus primarily on gathering support and involvement of organized constituencies outside the more formal education system and political structure.

In the past few years, the social sector has seen increased interest in and use of collective impact strategies that employ such coalition efforts to address particularly intractable and complex social problems. The concept of collective impact seems to have emerged from the Strive Together initiative in Cincinnati, which brought together local leaders to tackle the student achievement crisis in greater Cincinnati and northern Kentucky. Defining system change as community-wide transformation in which various partners (a) productively use data to improve their decision making and (b) constantly weigh the impact of their decisions on both their own institutions and the broader ecosystem that work to improve the lives of children, the leaders of Strive Together posited a four-pillar theory of action for collective impact: establishing a shared community vision, instituting evidence-based decision-making and shared accountability among the partners to improve selected outcomes, using continuous improvement approaches to identify and spread promising practices to improve community-level outcomes, and aligning financial and other resources to support and sustain improvement (Edmondson and Hecht 2014, 6-7).

Though Strive Together may have coined the phrase, others have instituted similar collective efforts, sometimes over decades (e.g., El Paso). All are based on the theme that cross-sector, cross-organization coordination is more likely to contribute to large-scale, sustained social change than are the isolated actions of individual organizations and agencies. Within this coordinated approach, the goal of eliminating 
disparities is a core principle. While such partnerships are not without their challenges, they not only lead to greater short-term success but can also build an infrastructure for identifying shared interests and maintaining a focus on addressing inequities across changes in superintendents and political environments.

In addition to grass-tops approaches like collective impact strategies, grass roots organizations and social movements can create pressure for maintaining focus on equal opportunities within and beyond education. One goal of communityorganizing efforts in education is to ensure the accountability of policy makers and local education leaders to students, parents, and the community for providing full opportunities to students in high-poverty communities and communities of color (Renee and McAlister 2011). The power of community organizing comes from the base of community members, rather than an elite set of leaders.

While much of community organizing is adversarial in nature, intended to keep up the pressure for addressing the needs of underserved students, organizing can also provide important support to local school districts. Working in conjunction with researchers and educators, local community members can help to identify problems requiring attention, gather data not available to most educators, and maintain consistency of focus across changes in leadership and conditions (Oakes and Lipton 2006). Such has been the case, for example, in efforts in Oakland and Los Angeles as these districts have confronted and eliminated discriminatory discipline and suspension policies that systematically denied children of color, particularly boys and young men, access to classroom instruction. ${ }^{63}$ Community organizing has contributed to documented success in increasing and more equitably distributing educational resources, ensuring access to college preparatory curricula, and establishing more effective recruitment and retention strategies in hard-to-staff schools.

\section{Conclusion}

We began this chapter with a brief review of how curtailed opportunities outside school exacerbate, and are exacerbated by, those inside the educational system to virtually disenfranchise large numbers of low-income students and students of color and perpetuate conditions of poverty across generations. We have offered a set of lessons from decades of education reform efforts and have applied those to

\footnotetext{
${ }^{63}$ For example, the Urban Strategies Council in Oakland was instrumental in analyzing data that led to an agreement between the district and the OCR to address egregious disparities in suspension and expulsions of African-American and Latino boys. In Los Angeles, community demonstrations supported efforts of the district administration to push for school board policies that ended use of the ambiguous and racially discriminatory "willful defiance" justification for suspension and that decriminalized all but the most dangerous infractions of school policy. Over a five-year period from 2007-2008 to 2012-2013, the suspension rate declined from 8.1 to $1.5 \%$, moving from almost 75,000 days lost to a little over 12,000. (See LA School Report, October 14, 2013. Retrieved at http://laschoolreport.com/la-unified-suspension-rate-accelerating-down-to-1-5-percent/) Keeping students in classrooms is a critical aspect of ensuring equity and access.
} 
sketching out how a more equitable system might operate. And we have suggested a three-pronged strategy of governmental action, professional networking and accountability, and public engagement and constituency building to provide the pressure and support for moving in this direction. But is such an approach possible at scale? Examples like Montgomery County, MD, and Long Beach, CA, provide some evidence of feasibility at the local level. But what about whole states-and, in particular, what about those that are currently failing so many of the nation's poor students and those of color?

Recent developments in California provide some basis for optimism and help demonstrate how the sources of pressure and support can possibly work together to turn a diverse and complex state in the direction of equity and long-term improvement. ${ }^{64}$ Let's be clear: We neither offer California as an exemplar of a mature continuously improving system, nor as one that has demonstrated extraordinary achievement for its traditionally underserved students. Rather, we suggest that the state has taken an important step forward, building a foundation for equity and improvement that was almost unimaginable even five short years ago.

Let's begin with a little context. California educates over 6.2 million students, or about one in every eight public school children in the U.S. California's students are among the most diverse and disadvantaged in the nation, with approximately $59 \%$ coming from low-income families, compared with $48 \%$ nationally ${ }^{65}$ Seventy-five percent are students of color, including $53 \%$ Hispanics, $9 \%$ Asian-Americans, and $6 \%$ African-Americans, among others. Over 1.4 million, or $23 \%$, of the state's students are officially classified as English language learners, compared to $9.1 \%$ nationally (Snyder 2014). California's ELLs represent by far the largest number and percent of such students among all U.S. states-indeed, almost one-third of English learners in the U.S. attend school in the Golden State.

The state has not done well by this increasingly diverse population of students. In 2013, California students who were eligible for free and reduced-price lunches ranked from $49^{\text {th }}$ (grade 4 math) to $42^{\text {nd }}$ (grade 8 reading) among similarly lowincome students in other states on NAEP. And achievement gaps (between Whites and African-Americans or Hispanic students and between those eligible and not eligible for the school lunch program) were similar to the corresponding gaps nationally, ranging from 25 to 33 points—or about 2.3 to three grade levels across both subjects and grades.

A major reason for this poor performance in the past few decades has been California's dysfunctional system of education-found "fundamentally flawed" by a massive independent investigation of the state's school finance and governance

\footnotetext{
${ }^{64}$ For a more detailed discussion of the current policy environment in California and the approach and actions that led to the changes, see O'Day 2015.

${ }^{65}$ These figures use eligibility for free and reduced price lunches as a proxy for low income. Data for California come from the California Department of Education Data Quest figures for 2013-14. The national figure is taken from the Southern Education Foundation (2013) and pertains to 2011 enrollment.
} 
systems in 2007 (Loeb et al. 2008, 8). Among the themes of the 23 independent reports of this "Getting Down to Facts" (GDTF) investigation were the following:

- Overregulation and proliferation of categorical funding streams had led to fragmentation, contradictory policies, and an emphasis on compliance over effective teaching and learning;

- Funding for education was sorely inadequate (lagging well behind national averages and difficult to increase due to Proposition 13's constitutional cap on property taxes), unnecessarily complex, and "inequitable by any measures";

- The state lacked a coherent system for recruiting, developing, and retaining highquality teachers; and

- Administrators had neither the data systems nor analytic capacity to enable system learning and improvement.

Mistrust and lack of leadership at the state level delayed action on the synthesis report's recommendations, and less than a year after it was released, California was plunged into a severe fiscal crisis. Already inadequate district budgets were slashed. Teachers and administrators were laid off, class sizes soared, and most legislators and education leaders were too busy treading water to see a way forward.

That was six years ago. Today the policy landscape and prospects for the future have taken a decided turn for the better. Passage of Proposition 30 in November 2012 brought $\$ 6$ billion per year in new revenues into state coffers, directed primarily at K-12 and higher education (Fensterwald 2014). The Local Control Funding Formula (LCFF) passed in June 2013 has simplified the school finance system, ensured greater equity for targeted student populations across (and hopefully within) school districts, and provided flexibility so that local educators can develop coherent strategies for serving their students and communities. Moreover, stakeholder groups across the state-including the California Teachers Association, state legislators and administrators, higher education and business leaders, advocacy groups, and local educators-have united in support of the Common Core State Standards, and the state legislature allocated an additional $\$ 1.25$ billion explicitly for implementation in 2013. Perhaps most surprising, the prevalent attitude appears to be on digging in for the long haul, and talk of "capacity building" and "continuous improvement" have become more common, even among politicians in Sacramento.

Many factors have combined to create this new window of opportunity in California education. We highlight a few of these, using the framework of the three sources of pressure and support outlined in the previous section.

\section{Restraining the Role of Government: Focusing on the Long Term}

California is an excellent example of how restraining and focusing the role of government can lay the groundwork for greater equity and improvement. With the election of Jerry Brown in 2010, the state's leadership team set out a methodical plan to 
accomplish two goals: right the broken funding and governance system, and provide coherent support for deep transition to the Common Core at the school and classroom levels. A first step was restoring funding for education as the state began its economic recovery; without this move, the other steps would have been difficult, if not impossible, both politically and fiscally. But at the heart of the fiscal transformation has been passage and implementation of the LCFF, which has two major components: (a) a more equitable allocation formula to districts, based on the numbers of students, with additional weights for counts and concentrations of students in poverty, English learners, and foster youth; and (b) the removal of categorical funding streams, and with them, the myriad of conflicting, burdensome, and top-down regulations that made it difficult for local districts to develop coherent, contextspecific improvement strategies.

The second focus has been to support effective implementation of the Common Core. The governor, State Board of Education, Department of Education, and state legislature have all united around this goal, and the legislature's allocation of an additional $\$ 1.25$ billion for capacity building for Common Core standards implementation had both symbolic and material benefits toward its realization. In addition, policies for curriculum and instructional guidance (recommendations of texts and development of instructional frameworks), teacher licensure, admissions criteria for the state's public universities, and accountability systems have been or are being aligned to support Common Core implementation. Each of these areas reflects the same state restraint as in LCFF, with the state playing a supportive and advisory role and placing much greater discretion with districts to respond to their local contexts.

Perhaps one of the boldest and most illustrative moves of the state was the decision to end use of the existing California Standards Tests in spring 2014, before the new Common Core standards-aligned assessments were ready for full implementation. Believing that continued administration of the old tests would send mixed signals to teachers and schools - and recognizing that students and adults could benefit from a run-through with the new assessment formats and technology-state leaders pushed back against accountability demands from the federal government and instead expanded the Smarter Balanced Assessment Consortium (SBAC) field test to include all students in the relevant grades across the state. This move was accompanied by a systematic collection and analysis of data on the implementation of the field test to inform state and local leaders about their readiness for the official SBAC administration set for spring 2015.

State leaders have also maintained focus by eschewing "reforms" that they believed were not in the best interests of the state or would detract from the fiscal and Common Core foci. Most notably, they declined to apply for an NCLB waiver because it would have required creation of a state test-based teacher evaluation system, which they felt would both violate state law and jeopardize the emerging coalition in support of Common Core implementation. 


\section{Building Public and Stakeholder Constituency for Improvement}

None of the changes above would have been possible without the ongoing mobilization both of the leaders ("grass tops") of education stakeholder groups in the state and grassroots organizing among parents and voters in the communities. Community organizers along with statewide advocacy groups and professional associations rallied support for passage of Proposition 30 in 2012, which brought new dollars into the system through institution of a tax on the wealthiest $3 \%$ of Californians. These same organizations remained active in the massive effort to press the state legislature to pass LCFF and have been involved in providing input into its refinement over the past two years. Indeed, local community and parent input is a core requirement in the development of the Local Control Accountability Plan, in which each district outlines its locally determined goals and allocations for addressing the general state priorities in education.

The momentum and sense of accomplishment from the successful LCFF campaign has also carried over to a sense of optimism and common purpose around Common Core implementation. Informal stakeholder meetings in 2013 led to the formation of a statewide Consortium for Implementation of the Common Core, with involvement from state agencies, local districts, county offices of education, charter management organizations, business, higher education, advocacy groups, teachers unions, and professional associations. The purpose of this consortium is to enable coordination of effort, fill in gaps where needed and feasible, and maintain an active broad-based constituency of support for continuous improvement and standards implementation.

\section{Leveraging and Strengthening Professional Networks}

Of course, the heart of educational improvement relies on building professional engagement, commitment, and capacity_including the needed social capital to spread more effective practices. In California this has taken the form of involving professional associations and the teachers unions in Common Core coalitions, as well as mobilizing professional networks like the California Subject Matter Projects to focus teacher attention and learning on the knowledge and practices needed for effective Common Core-aligned instruction. Leading districts in the state have provided exemplars of continuous improvement strategies, and networks and partnerships of local districts have generated opportunities for focused learning across contexts and across levels of the systems involved.

A combination of pressure and support from each of these arenas has been instrumental in laying the foundation for a more equitable state education system and one that enables rather than precludes a continuous, standards-based approach to improvement. Yet California's progress in this direction is still precarious, and several key challenges face state policy makers and local educators over the next few years. 
First, it is unclear what will happen when the expectedly low results of the new SBAC assessments are released in summer 2015: Will the public and its politicians have the patience for the long-term improvement process needed? Second, it is also unclear whether the local planning processes put in place for LCFF will generate the kinds of strategic coherence and consistency needed to ensure deep and equitable implementation of the new standards. Trust between equity advocates and local educators is still inchoate, and LCFF remains an experiment in the eyes of many. If results for traditionally underserved students are insufficiently transparent or compelling, the pullback to categorical funding streams and requirements will be strong-and demoralizing. A third challenge is the as-yet-undefined nature of the new accountability system and the lack of a unified vision for accountability that can actually support continuous improvement. Finally, the greatest challenge is the most obvious: How will the state build the individual and organizational capacity at the local level to enable the instructional shifts in classrooms across the state? California has almost 300,000 teachers, and they carry the burden for success of the Common Core and of the education enterprise more generally. Establishing the infrastructure to support them in this transition is an unprecedented challenge that the state has yet to fully address.

We have ended with an extended description of the situation in California because we believe that it provides reasons for hope as well as lessons for other states and jurisdictions. If we can move education in the most complex and challenging state system in the country, then other less troubled and more successful systems should also be able to make progress. California's example suggests the importance of both leadership and stakeholder engagement, of flexibility combined with coherence and focus, and of adequacy and equity of resources.

It also suggests the magnitude of the challenge to take such a vision to all of the other 49 states. Yet, there is hope and some evidence that change is possible. There are scattered examples of states such as Massachusetts and Texas that have proposed reforms and stayed with them over at least a decade. A substantial number of districts across the country have moved toward continuous improvement models as the core of their reforms, based on a growing recognition that accountability without investment in improvement does not work. Networks of superintendents and teachers exist in many states. Almost everyone in education understands we need standards and curricula that prepare students for intellectually rigorous work and that teachers need substantial support to implement the new curricula. Many of the ingredients for serious reform exist-this story is not over.

Open Access This chapter is distributed under the terms of the Creative Commons AttributionNoncommercial 2.5 License (http://creativecommons.org/licenses/by-nc/2.5/) which permits any noncommercial use, distribution, and reproduction in any medium, provided the original author(s) and source are credited.

The images or other third party material in this chapter are included in the work's Creative Commons license, unless indicated otherwise in the credit line; if such material is not included in the work's Creative Commons license and the respective action is not permitted by statutory regulation, users will need to obtain permission from the license holder to duplicate, adapt or reproduce the material. 


\section{References}

Abelmann, Charles, Richard Elmore, Johanna Even, Susan Kenyon, and Joanne Marshall. 1999. When accountability knocks, will anyone answer? CPRE Research Report RR-42. Philadelphia: University of Pennsylvania, Consortium for Policy Research in Education.

Adamson, Frank, and Linda Darling-Hammond. 2011. Speaking of salaries: What it will take to get qualified, effective teachers in all communities. Washington, DC: Center for American Progress.

Allensworth, Elaine M., and John Q. Easton. 2007. What matters for staying on track and graduating in Chicago public high schools. Chicago, IL: Consortium on Chicago School Research. Accessed 17 Dec 2014.

Anderson, Eric M., and James C. Gulek. 2008. Evaluation of MAP2D elementary math program. Long Beach Unified School District, Office of Research, Planning and Evaluation.

Austin, James E., Jennifer M. Suesse, and Robert B. Schwartz. 2004. Long Beach Unified School District (A): Change that leads to improvement (1992-2002). Cambridge, MA: Harvard University, Public Education Leadership Project.

Austin, James E., Allen Grossman, Robert B. Schwartz, and Jennifer M. Suesse. 2006. Managing at Scale in the Long Beach Unified School District. Cambridge, MA: Harvard University, Public Education Leadership Project.

Beaver, Jessica K., and Elliot H. Weinbaum. 2012. Measuring school capacity, maximizing school improvement, CPRE Policy Brief RB-53. Philadelphia: University of Pennsylvania, Consortium for Policy Research in Education.

Berger, Andrea, Nancy Adelman, and Susan Cole. 2010. The early college high school initiative: An overview of five evaluation years. Peabody Journal of Education 85(3): 333-347.

Berliner, David. 2011. Rational responses to high stakes testing: The case of curriculum narrowing and the harm that follows. Cambridge Journal of Education 41(3): 287-302.

Bialystok, Ellen. 2011. Reshaping the mind: The benefits of bilingualism. Revue Canadienne de Psychologie Expérimentale (Canadian Journal of Experimental Psychology) 65(4): 229-235.

Black, Paul, and Dylan Wiliam. 2009. Developing the theory of formative assessment. education assessment evaluation and accountability 21: 5-31. http://teacherscollegesj.edu/docs/47-devel opingthetheoryofformativeassessment_12262012101200.pdf.

Bohrnstedt, George W., and Brian M. Stecher (eds.). 2002. What we have learned about class size reduction in California. Sacramento: California Department of Education.

Boser, Ulrich, Megan Wilhelm, and Robert Hanna. 2014. Power of the Pygmalion effect: Teachers' expectations strongly predict college completion. Washington, DC: Center for American Progress.

Bransford, John D., Ann L. Brown, and Rodney R. Cocking. 2015. How people learn: Brain, mind, experience, and school, Expanded ed. Washington, DC: National Academies Press.

Bryk, Anthony S., Penny Bender Sebring, Elaine Allensworth, John Q. Easton, and Stuart Luppescu. 2010. Organizing schools for improvement: Lessons from Chicago. Chicago: University of Chicago Press.

Bryk, Anthony, M. Louis, and Grunow Alicia. 2011. Getting ideas into action: Building networked improvement communities in education. In Frontiers in sociology of education, ed. Maureen T. Hallinan. New York: Springer.

Caldas, Stephen J., and Carl Bankston. 1997. Effect of school population socioeconomic status on individual academic achievement. Journal of Educational Research 90(5): 269-277.

Carter, Samuel Casey. 1999. No excuses: Lessons from 21 high-performing high-poverty schools. Washington, DC: The Heritage Foundation.

Cawelti, Gordon. 2006. The side effects of NCLB. Educational Leadership 64(3): 64-68.

Children's Defense Fund. 2014. The State of America's children: 2014. Washington, DC: Author.

Clotfelter, Charles T., Helen F. Ladd, and Jacob L. Vigdor. 2010. Teacher credentials and student achievement in high school a cross-subject analysis with student fixed effects. Journal of Human Resources 45(3): 655-681. 
Cohen, David K., Stephen W. Raudenbush, and Deborah Loewenberg Ball. 2003. Resources, instruction, and research. Educational Evaluation and Policy Analysis 25(2): 119-142.

Coleman, James S. 1988. Social capital in the creation of human capital. American Journal of Sociology 94(4): S95-S120.

Consortium for Policy Research in Education. 2013. Evaluation of the i3 scale-up of reading recovery: Year one report, 2011-2012, CPRE Research Report-76. Philadelphia: University of Pennsylvania, Consortium for Policy Research in Education.

Cunningham, Patricia M. 2006. High-poverty schools that beat the odds. The Reading Teacher 60(4): 382-385.

David, Jane L., and Joan E. Talbert. 2013. Turning around a high-poverty district: Learning from Sanger. San Francisco: Cowell Foundation.

Deming, David. 2009. Early childhood intervention and life-cycle skill development: Evidence from Head Start. American Economic Journal: Applied Economics 3(3): 111-34.

Dixon, Mark. 2014. Public education finances: 2012: 2012 Census of governments. Washington, DC: U.S. Census Bureau. http://www.census.gov/content/dam/Census/library/publications/2014/econ/g12-cg-aspef.pdf.

Dobbie, Will, and Roland G. Fryer Jr. 2011. Are high-quality schools enough to increase achievement among the poor? Evidence from the Harlem children's zone. American Economic Journal: Applied Economics 3(3): 158-87.

Duffy, Helen, Jim Brown, Stephanie Hannan, and Jennifer O'Day. 2011. Separate paths, common goals: Cross-district collaboration on mathematics and english learner instruction. San Mateo: California Collaborative on District Reform.

Duncan, Greg J., and Richard J. Murnane. 2014. Restoring opportunity: The crisis of inequality and the challenge for American education. Cambridge, MA: Harvard Education Press.

Durlak, Joseph A., Roger P. Weissberg, Allison B. Dymnicki, Rebecca D. Taylor, and Kriston B. Schellinger. 2011. The impact of enhancing students' social and emotional leaning: A metaanalysis of school-based universal interventions. Child Development 82(1): 405-432.

Dweck, Carol S. 2006. Mindset: The new psychology of success. New York: Random House.

Dweck, Carol. 2012. Boosting achievement with messages that motivate, Canadian Education Association. http://www.lib.usf.edu/tutoring/files/2012/02/Boosting_Achievement_Spring07Dweck.pdf.

Edmondson, Jeff, and Ben Hecht. 2014. Defining quality collective impact. Stanford Social Innovation Review 8 (Fall), 6-7.

Equity and Excellence Commission. 2013. For each and every child: A strategy for education equity and excellence. Washington, DC: Author. http://www2.ed.gov/about/bdscomm/list/eec/ equity-excellence-commission-report.pdf.

Fensterwald, John. 2014. "Latest—but outdated-Ed Week survey ranks California $50^{\text {th }}$ in per pupil spending." EdSource Today, January 14, 2014.

Finnigan, Kara S., and Betheny Gross. 2007. Do accountability policy sanctions influence teacher motivation? Lessons from Chicago's low-performing schools. American Educational Research Journal 44(3): 594-630.

Fry, Richard, and Paul Taylor. 2012. The rise of residential segregation by income. Washington, DC: Pew Research Center.

Gawande, Atul. 2013. Slow ideas: Some innovations spread fast. How do you speed the ones that don't? New Yorker, July 29, 2013.

Gibbs, Chloe, Jens Ludwig, and Douglas L. Miller. 2011. Does Head Start do any lasting good? Working Paper 17452. Cambridge, MA: National Bureau of Economic Research.

Goldenberg, Claude. 2008. Teaching english language learners what the research does-and does not—say. American Educator 32(2): 8-44.

Grannis, Kerry S., and Isabel V. Sawhill. 2013. Improving children's life chances: Estimates from the Social Genome Model. Washington, DC: Brookings Institution.

Hargreaves, Andy, and Henry Braun. 2013. Data-driven improvement and accountability. Boulder: National Education Policy Center. 
Hargreaves, Andy, and Michael Fullan. 2012. Professional capital: Transforming teaching in every school. New York: Teachers College Press.

Hart, Betty, and Todd L. Risley. 1995. Meaningful differences in the everyday experience of young American children. Baltimore: Brookes Publishing.

Heckman, James. 2011. The economics of inequality: The value of early childhood education. American Educator 2011, 34-47. https://www.aft.org//sites/default/files/periodicals/Heckman. pdf.

Henry, Gary T., C. Kevin Fortner, and Kevin C. Bastian. 2012. The effects of experience and attrition for novice high-school science and mathematics teachers. Science 335(6072): $1118-1121$.

Honan, James P., Jennifer M. Suesse, and Robert B. Schwartz. 2004. Long beach unified school district (B): Working to sustain improvement (2002-2004). Cambridge, MA: Public Education Leadership Project, Harvard University.

Houck, Eric A., and Elizabeth DeBray. Forthcoming. The shift from adequacy to equity in federal education policymaking: A proposal: How ESEA could reshape the state role in education finance. New York: Russell Sage Foundation.

Ingersoll, Richard M. 2004. Why do high-poverty schools have difficulty staffing their classrooms with qualified teachers? Washington, DC: Center for American Progress and Institute for America's Future.

Ingersoll, Richard, Lisa Merrill, and Daniel Stuckey. 2014. Seven trends: The transformation of the teaching force, updated April 2014, CPRE Report RR-80. Philadelphia: University of Pennsylvania, Consortium for Policy Research in Education.

Isenberg, Eric, Jeffrey Max, Phillip Gleason, Liz Potamites, Robert Santillano, Heinrich Hock, and Michael Hansen. 2013. Access to effective teaching for disadvantaged students. Washington, DC: Institute for Educational Sciences.

Jennings, Jack. 2015. Presidents, Congress, and the public schools: The politics of education reform. Cambridge, MA: Harvard Education Press.

Johnson, Evelyn S., Juli Pool, and Deborah R. Carter. n.d. Screening for reading problems in grades 4 through 12. New York: RTI Action Network, http://www.rtinetwork.org/essential/ assessment/screening/screening-for-reading-problems-in-grades-4-through-12.

Jyoti, Diana F., Edward A. Frongillo, and Sonya J. Jones. 2005. Food insecurity affects school children's academic performance, weight gain, and social skills. Journal of Nutrition 135(12): 2831-2839.

Kane, Thomas, J., Jonah E. Rockoff, and Douglas O. Steiger. 2006. What does certification tell us about teacher effectiveness? Evidence from New York city, NBER Working Paper 12155. Cambridge, MA: National Bureau of Economic Research. http://www.nber.org/papers/ w12155.pdf.

Kannapel, Patricia. J., and Stephen K. Clements, with Diana Taylor and Terry Hibpshman. 2005. Inside the black box of high-performing high-poverty schools. Lexington: Prichard Committee for Academic Excellence.

Kieffer, Michael J., William H. Marinell, and Nicky Stephenson. 2011. The middle grade student transitions study: Navigating the middle grades and preparing students for high school graduation. New York: New York University, Research Alliance for New York City Schools. http:// steinhardt.nyu.edu/scmsAdmin/media/users/jnw216/RANYCS/WebDocs/MiddleGradesTransitionsWorkingBrief-Final.pdf.

Kirp, David L. 2013. Improbable scholars: The rebirth of a great American school system and a strategy for America's schools. Oxford: Oxford University Press.

Knudson, Joel. 2013. You'll never be better than your teachers: The Garden Grove approach to human capital development. San Mateo: California Collaborative on District Reform. http:// cacollaborative.org/publication/youll-never-be-better-your-teachers-garden-grove-approachhuman-capital-development. 
Langley, Gerald J., Moen Ronald, Kevin M. Nolan, Thomas W. Nolan, Clifford L. Norman, and Lloyd P. Provost. 2009. The improvement guide: A practical approach to enhancing organizational performance. San Francisco: Jossey-Bass.

Latimer, Jeff, and Steven Kleinknecht. 2000. The effects of restorative justice program: A review of the empirical. Ottawa: Department of Justice Ottawa, Canada.

Lhamon, Catherine E. 2014. Dear colleague letter: Resource comparability. Washington, DC: Office of Civil Rights, U.S. Department of Education, October 1. http://www2.ed.gov/about/ offices/list/ocr/letters/colleague-resourcecomp-201410.pdf.

Lippman, Laura, Shelley Burns, and Edith McArthur, Statistics. 1996. Urban schools: The challenge of location and poverty, Washington, DC: U.S. Department of Education, National Center for Education Statistics. http://nces.ed.gov/pubs/96184all.pdf.

Loeb, Susanna, Anthony Bryk, and Eric Hanushek. 2008. Getting down to facts: School finance and governance in California. Education Finance and Policy 3(1): 1-19.

Marian, Viorica, Anthony Shook, and Scott R. Schroeder. 2013. Bilingual two-way immersion programs benefit academic achievement. Bilingual Research Journal 36: 167-186.

Massey, Douglas S., and Nancy A. Denton. 1993. American apartheid: Segregation and the making of the underclass. Cambridge, MA: Harvard University Press.

McClintock, Nathan. 2008. From industrial garden to food desert: Unearthing the root structure of urban agriculture in Oakland CA, ISIS Fellows Working Paper 2007-08.32. Berkeley: University of California-Berkeley, Institute for the Study of Societal Issues. http://escholarship. org/uc/item/1wh3v1sj.

McLaughlin, Milbrey Wallin. 1987. Learning from experience: Lessons from policy implementation. Educational Evaluation and Policy Analysis 9(2): 171-178.

McLaughlin, Milbrey, and Joan Talbert. 2001. Professional communities and the work of high school teaching. Chicago: The University of Chicago Press.

Messick, Samuel. 1989. Validity. In Educational measurement, 3rd ed, ed. R.L. Linn, 13-103. New York: American Council of Education.

Meyer, Anne, David H. Rose, and David Gordon. 2014. Universal design for learning: Theory and practice, Wakefield: CAST. http://www.cast.org/our-work/publications/2014/universal-designlearning-theory-practice-udl-meyer.html\#.VTa1cGbxpek.

Murnane, Richard J. 2013. U.S. high school graduation rates: Patterns and explanations. Journal of Economic Literature 51(June): 370-422.

Neild, Ruth C. 2009. Falling off track during the transition to high school: What we know and what could be done. The Future of Children 19 (1). http://futureofchildren.org/publications/journals/ article/index.$x m l$ ?journalid=30andarticleid=38andsectionid $=84$.

New America Foundation. 2012. School finance inequity. Federal Education Budget Project. http:// febp.newamerica.net/k12/rankings/schofiineq/print.

Newmann, Fred M., Bets Ann Smith, Elaine Allensworth, and Anthony S. Bryk. 2001. Instructional program coherence: What it is and why it should guide school improvement policy. Educational Evaluation and Policy Analysis 23(4): 297-321.

Oakes, Jeannie, and Martin Lipton. 2006. Teaching to change the world, 3rd ed. New York: McGraw-Hill Higher Education.

O’Day, Jennifer A. 1996. Introduction: Incentives and improvement. In Rewards and reform: Creating educational incentives that work, ed. Susan H. Fuhrman and Jennifer A. O'Day, 1-16. San Francisco: Jossey-Bass.

O’Day, Jennifer A. 2002. Complexity, accountability, and school improvement. Harvard Educational Review 72(3): 293-329.

O'Day, Jennifer A. 2008. NCLB and the complexity of school improvement. In No Child Left Behind and the reduction of the achievement gap: Sociological perspectives on federal educational policy, ed. Alan R. Sadovnik, Jennifer A. O’Day, George W. Bohrnstedt, and Kathryn M. Borman. London: Routledge.

O'Day, Jennifer A. 2015. A window of opportunity: The politics and policies of Common Core implementation in California. In Challenging standards: Navigating conflict and building 
capacity in the era of the Common Core, ed. Jonathan A. Supovitz and Spillane James. Lanham: Rowman \& Littlefield Publishers.

O'Day, Jennifer A., and Marshall Smith. 1993. Systemic reform and educational opportunity. In Designing coherent education policy: Improving the system, ed. Susan Fuhrman, 250-312. San Francisco: Jossey-Bass.

Orfield, Gary. 2009. Reviving the goal of an integrated society: A 21st century challenge. Los Angeles: Civil Rights Project/Proyecto Derechos Civiles. January.

Orfield, Gary. 2013. Housing segregation produces unequal schools: Causes and solutions. In Closing the achievement and opportunity gap: What America must do to give every child an even chance, ed. Prudence L. Carter and Kevin G. Welner, 40-60. New York: Oxford University Press.

Owens, Ann, Sean F. Reardon, and Christopher Jencks. 2014. Trends in school economic segregation, 1970 to 2010. http://cepa.stanford.edu/content/trends-school-economic-segregation1970-2010.

Papay, John, P., and Matthew A. Kraft. Forthcoming. Productivity returns to experience in the teacher labor market: Methodological challenges and new evidence on long-term career improvement. Journal of Economics.

Park, Sandra, Stephanie Hironaka, Penny Carver, and Nordstrum Lee. 2012. Continuous improvement in education. Stanford: Carnegie Foundation.

Perry, Laura, and Andrew McConney. 2010. Does the SES of the school matter? An examination of socioeconomic status and student achievement using PISA 2003. Teachers College Record 112(4): 7-8.

Purkey, Stewart C., and Marshall S. Smith. 1983. Effective schools: A review. Elementary School Journal 83(4): 427-452.

Raudenbush, Stephen W., Marshall Jean, and Emily Art. 2011. Year-by-year cumulative impacts of attending a high-mobility elementary school on children's mathematics achievement in Chicago, 1995-2005. In Whither opportunity: Rising inequality, schools, and children's life chances, ed. Greg J. Duncan and Richard J. Murnane. New York: Russell Sage.

Raymond, Margaret E., Edward Cremata, Devora Davis, Kathleen Dickey, Kristina Lawyer, Yohannes Negassi, Margaret E. Raymond, and James L. Woodworth. 2013. National charter school study. Stanford: Center for Research on Educational Outcomes, Stanford University.

Reardon, Sean F. 2011. The widening academic achievement gap between the rich and the poor: New evidence and possible explanations. In Whither opportunity: Rising inequality, schools, and children's life chances, ed. Greg J. Duncan and Richard J. Murnane. New York: Russell Sage.

Reardon, Sean F., and Kendra Bischoff. 2011. Income inequality and income segregation. American Journal of Sociology 116(4): 1092-1153.

Reeves, Douglas B. 2003. High performance in high poverty schools: 90/90/90 and beyond. Englewood: Center for Performance Assessment.

Renee, Michelle, and Sara McAlister. 2011. The strengths and challenges of community organizing as a reform strategy: What the research says. Providence: Brown University, Annenberg Institute for Reform.

Roderick, Melissa, Thomas Kelley-Kemple, David W. Johnson, and Nicole O. Beechum. 2014. Preventable failure: Improvements in long-term outcomes when high schools focused on the ninth grade year. Chicago: Consortium on Chicago School Research.

Rogers, Everett, Arvind Singhal, and Margaret Quinlan. 2009. Diffusion of innovations. In An integrated approach to communication theory and research, ed. Don W. Stacks and Michael B. Salwen. London: Routledge.

Rothstein, Richard. 2013. For public schools, segregation then, segregation since: Education and the unfinished march. Washington, DC: Economic Policy Institute. http://s2.epi.org/files/2013/ Unfinished-March-School-Segregation.pdf. 
Rowan, Brian. 1996. Standards as incentives for instructional reform. In Rewards and reform: Creating educational incentives that work, ed. Susan H. Fuhrman and Jennifer A. O'Day. San Francisco: Jossey-Bass.

Rumberger, Russell W., and Gregory J. Palardy. 2005. Does segregation still matter? The impact of student composition on academic achievement in high school. Teachers College Record 107(9): 1999-2045.

Schmidt, William H., and Curtis C. McKnight. 2012. Inequality for all: The challenge of unequal opportunity in American schools. New York: Teachers College Press.

Schoen, La. Tefy, and Lance D. Fusarelli. 2008. Innovation, NCLB, and the fear factor: The challenge of leading 21st-century schools in an era of accountability. Educational Policy 22(1): $181-203$.

Simon, Nicole S., and Susan Moore Johnson. 2013. Teacher turnover in high-poverty schools: What we know and can do. Working Paper, Project on the next generation of teachers. Cambridge, MA: Harvard Graduate School of Education. http://isites.harvard.edu/fs/docs/icb. topic1231814.files/Teacher\%20Turnover\%20in\%20High-Poverty\%20Schools.pdf.

Smith, Marshall S., and Jennifer A. O'Day. 1991. Systemic school reform. In The Politics of curriculum and testing, Politics of Education Association yearbook 1990, ed. Susan Fuhrman and Betty Malen, 233-267. London: Falmer Press.

Snow, Catherine, Susan M. Burns, and Peg Griffin. 1998. Preventing reading difficulties in young children. Washington, DC: National Academy Press.

Snyder, Thomas D. 2014. Mobile digest of education statistics, 2013 (NCES 2014-085). Washington, DC: U.S. Department of Education, National Center for Education Statistics, Institute of Educational Sciences.

Southern Education Foundation. 2015. A new majority: Low income students now a majority in the nation's public schools. Research Bulletin (January). http://www.southerneducation.org/ getattachment/4ac62e27-5260-47a5-9d02-14896ec3a531/A-New-Majority-2015-UpdateLow-Income-Students-Now.aspx

Southern Regional Education Board (SREB). 2010. Beyond the rhetoric: Improving college readiness through coherent state policy, June. http://www.highereducation.org/reports/college_ readiness/.

Spillane, James P., Brian J. Reiser, and Louis M. Gomez. 2006. Policy implementation and cognition: The role of human, social, and distributed cognition in framing policy implementation. In New directions in education policy implementation, ed. Meredith I. Honig, 47-64. Albany: SUNY Press.

Stetser, Marie, and Robert Stillwell. 2014. Public high school four-year on-time graduation rates and event dropout rates: School years 2010-11 and 2011-12: First look, NCES 2014-391. Washington, DC: U.S. Department of Education. National Center for Education Statistics.

Stiglitz, Joseph E. 2012. The price of inequality. New York: W.W. Norton.

Stullich, Stephanie. 2011. The potential impact of revising the Title I comparability requirement to focus on school-level expenditures. Washington, DC: U.S. Department of Education. https:// www2.ed.gov/rschstat/eval/title-i/comparability-requirement/comparability-policy-brief.pdf.

Sykes, Gary, Jennifer O'Day, and Timothy Ford. 2009. The district role in instructional improvement. In Handbook on education policy research, ed. Gary Sykes, Barbara Schneider, and David N. Plank. New York: Routledge.

Symonds, William C., Robert Schwartz, and Ronald F. Ferguson. 2011. Pathways to prosperity: Meeting the challenge of preparing young Americans for the 21st century. Cambridge, MA: Harvard University Graduate School of Education, Pathways to Prosperity Project. http://dash. harvard.edu/bitstream/handle/1/4740480/Pathways_to_Prosperity_Feb2011-1.pdf?sequence=1.

Theokas, Christina, and Reid Saaris. 2013. Finding America's missing AP and IB students. Washington, DC: The Education Trust, June. http://1k9g11yevnfp2lpq1dhrqe17.wpengine. netdna-cdn.com/wp-content/uploads/2013/10/Missing_Students.pdf.

U.S. Department of Agriculture. 2009. Access to affordable and nutritious food: Measuring and understanding food deserts and their consequences-report to Congress. Washington, DC: Author. 
U.S. Department of Education. 2013. For each and every child—a strategy for education equity and excellence. Washington, DC: Author.

Vaughn, Sharon, Jack M. Fletcher, David J. Francis, Carolyn A. Denton, Jeanne Wanzek, Jade Wexler, Paul T. Cirino, Amy E. Barth, and Melissa A. Romain. 2008. Response to intervention with older students with reading difficulties. Learning and Individual Differences 18(3): 338345. doi:10.1016/j.lindif.2008.05.001.

Weast, Jerry D. 2014. Confronting the achievement gap: A district-level perspective. In Improving the odds for America's children: Future directions in policy and practice, ed. Kathleen McCartney, Hirokazu Yoshikawa, and Laurie B. Forcier. Cambridge, MA: Harvard Education Press.

Weatherley, Richard, and Michael Lipsky. 1977. Street-level bureaucrats and institutional innovation: Implementing special-education reform. Harvard Educational Review 47(2): 171-197.

Weiler, Erica. 2003. Making school safe for sexual minority students. Principal Leadership 4(4): 10-13. http://www.nassp.org/portals/0/content/48927.pdf.

Wenger, Etienne. 2000. Communities of practice and social learning systems. Organization 7(2): 225-246.

Yamada, Hiroyuik. 2014. Communities colleges pathways' program success: Assessing the first two years' of effectiveness of statway. Washington, DC: Carnegie Foundation for the Advancement of Teaching, November.

Yoshikawa, Hirokazu, Christina Weiland, Jeanne Brooks-Gunn, Margaret R. Burchinal, Linda M. Espinosa, William T. Gormley, Jens Ludwig, Katherine A. Magnuson, Deborah Phillips, and Martha J. Zaslow. 2013. Investing in our future: The evidence base on preschool education. New York: Society for the Research on Child Development. 